\title{
Simulation of the Shallow Aquifer in the Vicinity of Silver Lake, Washington County, Wisconsin, Using Analytic Elements
}

Water-Resources Investigations Report 02-4204

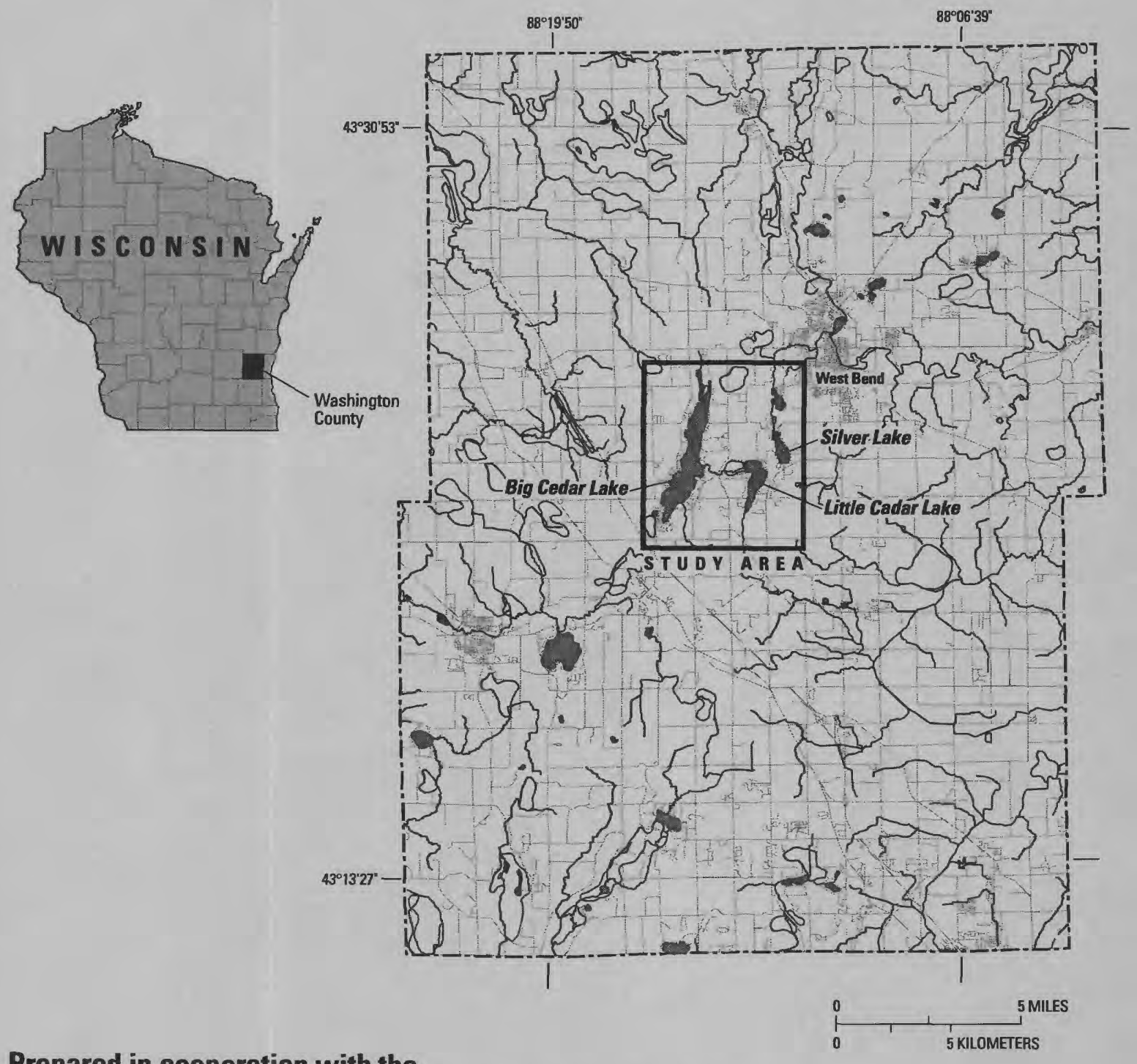

Prepared in cooperation with the Silver Lake Protection and Rehabilitation District

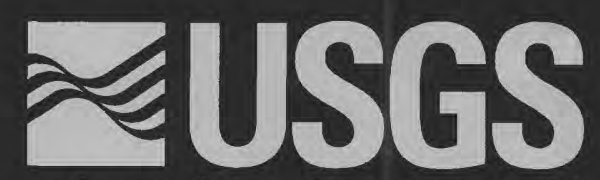




\section{Simulation of the Shallow Aquifer in the Vicinity of Silver Lake, Washington County, Wisconsin, Using Analytic Elements}

By C.P. Dunning, J.C. Thomas, and Y-F. Lin

U.S. GEOLOGICAL SURVEY

Water-Resources Investigations Report 02-4204

Prepared in cooperation with the

Silver Lake Protection and Rehabilitation District 


\title{
U.S. DEPARTMENT OF THE INTERIOR GALE A. NORTON, Secretary
}

\author{
U.S. GEOLOGICAL SURVEY \\ Charles G. Groat, Director
}

The use of firm, trade, and brand names in this report is for identification purposes only and does not constitute endorsement by the U.S. Government.

For additional information write to:

District Chief

U.S. Geological Survey

8505 Research Way

Middleton, WI 53562-3586
Copies of this report can be purchased from:

U.S. Geological Survey

Branch of Information Services

Box 25286

Denver, CO 80225-0286 


\section{CONTENTS}

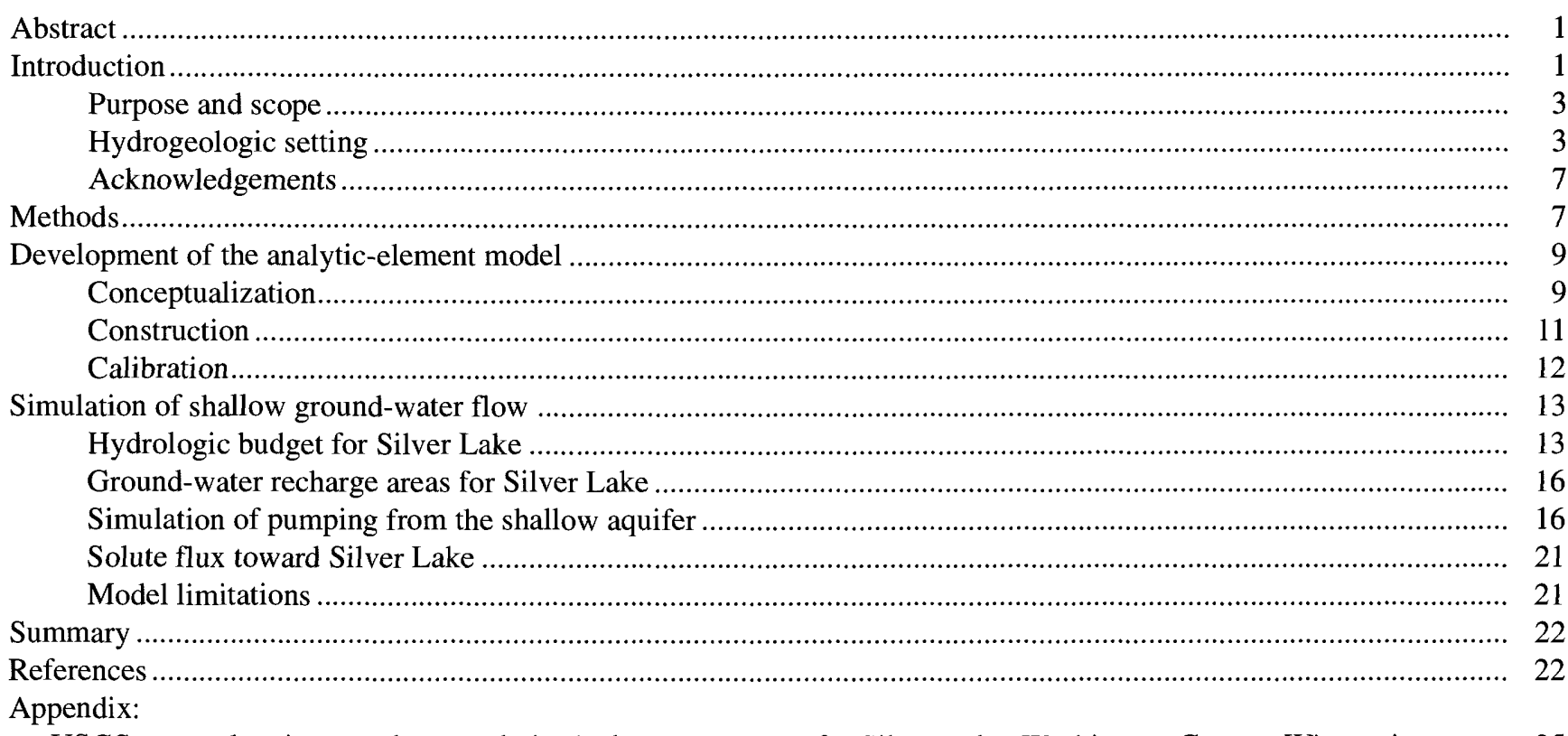

USGS water chemistry analyses and physical measurements for Silver Lake, Washington County, Wisconsin ........... 25

\section{FIGURES}

1-2. Maps showing:

1. Location of Washington County, Wisconsin, and Silver Lake study area .....................................................

2. Lakes, creeks, and glacial stratigraphy of the Silver Lake study area, Washington County, Wisconsin......... 4

3. Graph showing measured Silver Lake stage, flow to Silver Lake from southwest springs, and flow from

Silver Lake to Silver Creek, Washington County, Wisconsin, February-December, 1977

4. Map showing analytic elements and calibration targets in the Silver Lake model area, Washington County, Wisconsin.

5. Figure showing conceptual model, in cross-sectional view, of the interaction of lakes, precipitation, evaporation, and shallow ground-water-flow in the vicinity of Silver Lake, Washington County, Wisconsin ..

6. Map showing comparison of simulated to measured head targets in the calibrated Silver Lake, Washington County, Wisconsin, analytic-element model

7. Scatter plot comparing simulated heads to measured heads for the calibrated Silver Lake, Washington County, Wisconsin, analytic-element model

8-11. Maps showing:

8. Simulated water table from the calibrated Silver Lake, Washington County, Wisconsin, analytic-element model

9. Hydrologic budget for Silver Lake, Washington County, Wisconsin, based on the calibrated analyticelement model.

10. Ground-water recharge areas and times-of-travel to Silver Lake, Washington County, Wisconsin .............. 18

11a. Locations of three simulated wells around Silver Lake, Washington County, Wisconsin ............................ 19

11b. Simulated fully-penetrating well pumping 75 gallons per minute from west side of Silver Lake, Washington County, Wisconsin.....

11c. Simulated fully-penetrating well pumping 75 gallons per minute from east side of Silver Lake, Washington County, Wisconsin.

11d. Simulated fully-penetrating well pumping 75 gallons per minute from southeast side of Silver Lake, Washington County, Wisconsin 


\section{TABLES}

1. Summary of analytical results for water-quality samples from Silver Lake and other lakes in southeastern Wisconsin

2. Measured and simulated streamflow, Washington County, Wisconsin....

3. Resistance and width of lakes and streams in the Silver Lake, Washington County, Wisconsin, analytic-element model.

4. Relation of lake stage and discharge used for lake specified line-sink representing Silver Lake,

Washington County, Wisconsin, in the analytic-element model.

5. Average solute concentrations in ground water and resulting mass flux toward Silver Lake, Washington County, Wisconsin 
CONVERSION FACTORS, VERTICAL DATUM, AND ABBREVIATIONS

\begin{tabular}{|c|c|c|}
\hline Multiply & By & To Obtain \\
\hline \multicolumn{3}{|c|}{ Length } \\
\hline inch (in.) & 25.4 & millimeter $(\mathrm{mm})$ \\
\hline foot $(f t)$ & .3048 & meter (m) \\
\hline mile (mi) & 1.609 & kilometer $(\mathrm{km})$ \\
\hline acre $(\mathrm{ac})$ & 43,560 & square feet $\left(\mathrm{ft}^{2}\right)$ \\
\hline \multicolumn{3}{|c|}{ Discharge } \\
\hline cubic feet per day $\left(\mathrm{ft}^{3} / \mathrm{d}\right)$ & 8.32 & liters per day (L/d) \\
\hline cubic feet per second $\left(\mathrm{ft}^{3} / \mathrm{s}\right)$ & $2,446,575.5$ & liters per day $(\mathrm{L} / \mathrm{d})$ \\
\hline \multicolumn{3}{|c|}{ Hydraulic Conductivity ${ }^{\star}$} \\
\hline feet per day ( $\mathrm{ft} / \mathrm{d})$ & .3408 & meters per day $(\mathrm{m} / \mathrm{d})$ \\
\hline
\end{tabular}

Temperature in degrees Celsius $\left({ }^{\circ} \mathrm{C}\right)$ can be converted to degrees Fahrenheit $\left({ }^{\circ} \mathrm{F}\right)$ by use of the following equation:

$$
{ }^{\circ} \mathrm{F}=1.8\left({ }^{\circ} \mathrm{C}\right)+32 \text {. }
$$

Sea level: In this report, "sea level" refers to the National Geodetic Vertical Datum of 1929 (NGVD of 1929)-a geodetic datum derived from a general adjustment of the first-order level nets of both the United States and Canada, formerly called Sea Level Datum of 1929.

* Hydraulic conductivity: The standard unit for hydraulic conductivity is cubic foot per day per square foot of aquifer cross-sectional area $\left(\mathrm{ft}^{3} / \mathrm{d}\right) / \mathrm{ft}^{2}$. In this report, the mathematically reduced form, feet per day $(\mathrm{ft} / \mathrm{d})$, is used for convenience.

Transmissivity: Transmissivity is the product of horizontal hydraulic conductivity and saturated thickness.

Water year: Water year is the 12 month period from October 1 through September 30 . The water year is designated by the calendar year in which it ends.

Abbreviated water-quality units used in this report: Chemical concentration is given in milligrams per liter (mg/L). Milligrams per liter is a unit expressing the concentration of chemical constituents in solution as weight (milligrams) of solute per unit volume (liter) of water. One thousand micrograms per liter is equivalent to one milligram per liter.

Specific conductance is given in microsiemens per centimeter at 25 degrees Celsius $\left(\mu \mathrm{S} / \mathrm{cm}\right.$ at $\left.25^{\circ} \mathrm{C}\right)$.

Dissolved oxygen (DO) is given in milligrams per liter (mg/L).

\section{Other abbreviations used in this report}

$\mathrm{Kg} / \mathrm{d} \quad$ kilograms per day

$\mathrm{in} / \mathrm{yr} \quad$ inches per year 


\title{
Simulation of the Shallow Aquifer in the Vicinity of Silver Lake, Washington County, Wisconsin, Using Analytic Elements
}

\author{
By C.P. Dunning, J.C. Thomas, and Y-F. Lin
}

\section{Abstract}

Shallow ground-water flow in the vicinity of Silver Lake, Washington County, Wisconsin, was investigated to develop an understanding of the hydrology of the shallow aquifer, define a water balance for the lake, delineate ground-water recharge areas for the lake, and to estimate solute flux toward the lake. A single-layer, steady-state, analytic-element model was used to simulate shallow ground-water flow. Regional model parameters include a recharge rate of 4 inches per year, hydraulic conductivity of 50 feet per day and a model base of 800 feet above sea level. A model inhomogeneity was added to represent deviations from these regional values for an area roughly coincident with the Kettle Moraine Area that trends through the study area. Model calibration was accomplished by varying the regional parameter values and those of the inhomogeneity through trial-and-error to determine a best-fit match between simulated and measured values for head and streamflow targets. There was no change to the regional parameter values as a result of calibration, however, the calibrated values for the inhomogeneity are: recharge rate of 12 inches per year, hydraulic conductivity of 20 feet per day, and a model base of 900 feet. These changes represent a four- to five-fold reduction in transmissivity within the inhomogeneity as compared to the regional model.

A Silver Lake water budget was defined using both published hydrologic data and simulations using the calibrated model. Model simulations show that 1.08 cubic feet per second of ground water enters Silver Lake on the upgradient (primarily western) side and 0.08 cubic feet per second recharges to ground water on the downgra- dient (primarily eastern) side. Net precipitation (precipitation minus evaporation) on the lake is 0.04 cubic feet per second. Collectively, these water-budget terms provide a residual value of 1.04 cubic feet per second flow to Silver Creek at the north end of Silver Lake, which is a very good match to the range of measured flow (0.7 to 5.2 cubic feet per second). Ground-water recharge areas for Silver Lake are largely on the western side of the lake. The recharge area for the northern twothirds of Silver Lake is west toward Big Cedar Lake. Assuming a porosity of 20 percent, model results indicate that the 50-year time-of-travel for recharge to Silver Lake does not extend to Big Cedar Lake. The recharge area for the southern one-third of Silver Lake is west toward Little Cedar Lake. Model results indicate that time of travel for recharge to Silver Lake from Little Cedar Lake is about 15 to 20 years. For travel times greater than 15 or 20 years, the ground-water recharge area for Little Cedar Lake and inflow from Big Cedar Lake also should be considered recharge affecting Silver Lake. Solute flux toward Silver Lake was calculated based on simulated ground-water flux and measured concentrations in the upgradient piezometers and observation wells.

\section{INTRODUCTION}

Silver Lake is a ground-water seepage lake located in central Washington County, southeastern Wisconsin (fig. 1). Because of its strong hydraulic connection to shallow ground-water flow, Silver Lake could be affected adversely by stresses to the shallow aquifer. The shallow aquifer is defined here to comprise the unconsolidated glacial sediments, generally 100 to 300 feet thick, overlying the bedrock. In order to assess 


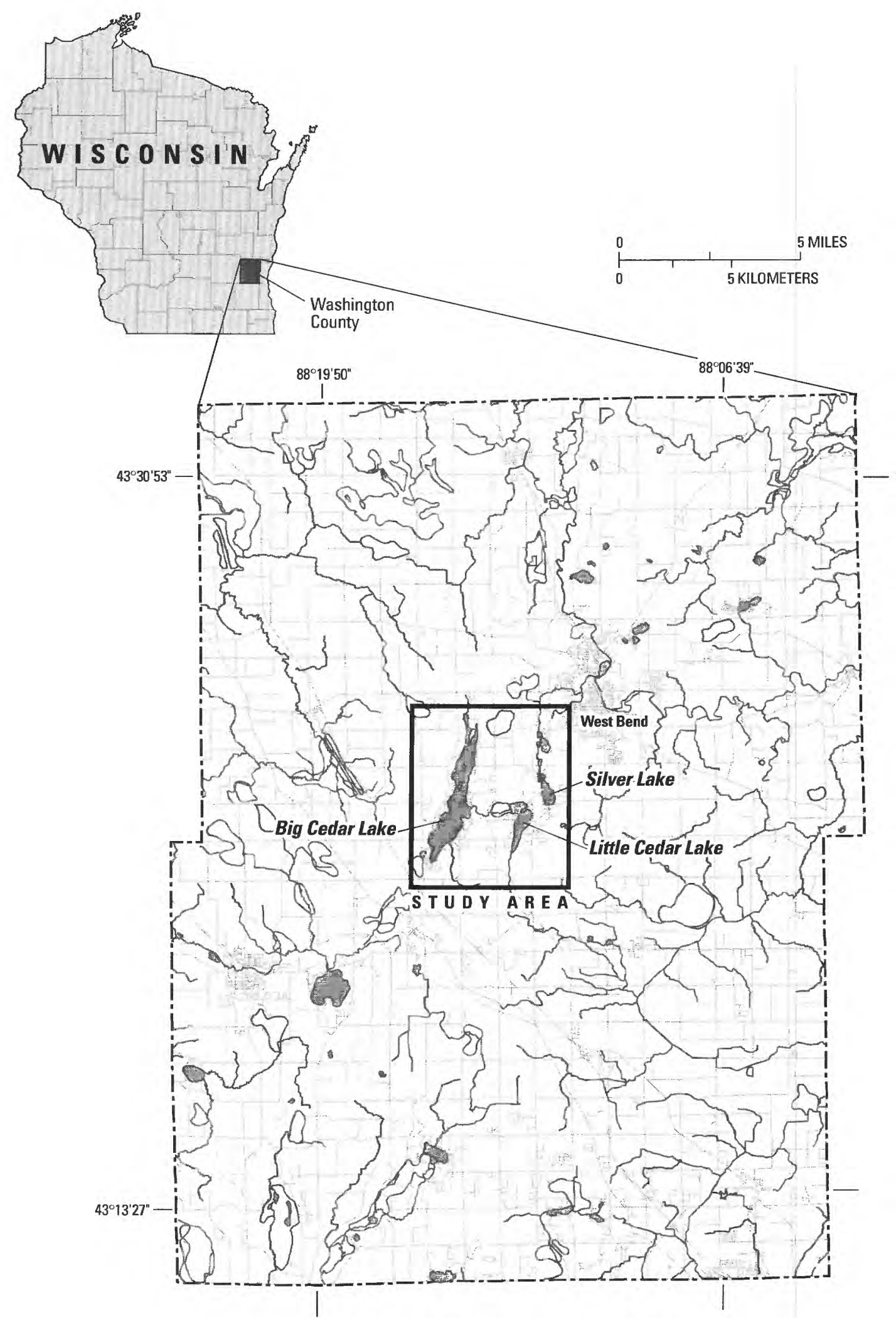

W A S H I N G T O N C O U N T Y

Figure 1. Location of Washington County, Wisconsin and Silver Lake study area. 
the potential effects on Silver Lake of stresses to the shallow aquifer, a study was undertaken in 2000 by the U.S. Geological Survey (USGS) in cooperation with the Silver Lake Protection and Rehabilitation District (SLPRD). The SLPRD was awarded a Lake Management Planning Grant for the study administered by the Wisconsin Department of Natural Resources. The study began in 2000 with the following objectives: (1) estimate hydraulic parameter values for the shallow aquifer, (2) determine a hydrologic budget for Silver Lake, (3) simulate the ground-water recharge areas for Silver Lake, and (4) estimate flux of selected solutes toward Silver Lake.

\section{Purpose and Scope}

This report discusses the hydrogeology of Silver Lake and the shallow aquifer, and presents groundwater simulation results that support the hydrologic interpretations. This report also includes information on available hydrologic data, new data collected during the study, the conceptualization of the hydrogeologic setting of Silver Lake and the shallow aquifer, details on model construction and calibration, a hydrologic budget, and delineation of ground-water recharge areas for Silver Lake. Ground-water solute flux toward the lake also is discussed. An analytical element model was used to simulate shallow ground-water flow in the study area.

\section{Hydrogeologic Setting}

Silver Lake is located in central Washington County, Wisconsin, southwest of the city of West Bend (fig. 1). In this part of the county, Silurian dolomite bedrock is overlain by 100 to $300 \mathrm{ft}$ of glacial sediments (Mickelson and Syverson, 1997). The altitude of the Silurian dolomite bedrock surface varies by hundreds of feet over the study area as a result of erosion by prePleistocene rivers and late-Pleistocene glaciers.

As the glaciers retreated between 15,000 and 13,000 years ago, sand and gravel derived from existing deposits or from the underlying dolomite bedrock were deposited on stagnant ice by meltwater streams flowing south. These deposits compose the shallow aquifer in central Washington County. Within the study area these glacial deposits are named the Holy Hill Formation (Mickleson and Syverson, 1997), of which two distinct members are recognized: the Horicon Member and the
New Berlin Member. An additional member consisting of intermixed Horicon and New Berlin Members is named Undifferentiated Deposits of the Holy Hill Formation (fig. 2). All three members are described as being "poorly to moderately well sorted, poorly to well stratified, gravel and sand" (Mickleson and Syverson, 1997). It is the Undifferentiated Member of the Holy Hill Formation that forms the Kettle Moraine Area (fig. 2) in southeastern Wisconsin. The term moraine identifies a distinct ridge of unsorted, unstratified glacial sediments (Bates and Jackson, 1980) deposited, in this case, between the retreating Green Bay and Lake Michigan lobes of the Wisconsinan glaciation. The term kettle identifies depressions formed in the moraine by the melting of ice blocks buried under the glacial sand and gravel (Bates and Jackson, 1980). Water has filled the lower-lying kettles creating the present-day lakes. Silver Lake and most of the other lakes of Washington County are aligned along the contacts between the Undifferentiated Member of the Holy Hill Formation and either the Horicon Member on the west or the New Berlin Member on the east (fig. 2).

Silver Lake is a seepage lake with springs, about 117.6 ac in area, with a maximum depth of $45 \mathrm{ft}$ (Poff and Threinen, 1962). Water flows north from Silver Lake into Silver Creek to Paradise Valley Lake (also known as Hackbarth Lake) and Lucas Lake (fig. 2). From Lucas Lake, Silver Creek flows into the Milwaukee River (not shown). West of Silver Lake lie Little Cedar Lake (246 ac) and Big Cedar Lake (932 ac). Water flows east from Big Cedar Lake through a stream and associated wetland to Little Cedar Lake, and then south from Little Cedar Lake into Cedar Creek. Neither of these lakes has a direct surface-water connection with Silver Lake or its associated downstream lakes.

No streams flow into Silver Lake; the lake is fed by ground-water seepage and small springs discharging near the shoreline (Poff and Threinen, 1962). The primary spring complex is found on the southwest shore of the lake, and flow was measured during 1976 and 1977 to be a nearly constant $0.1 \mathrm{ft}^{3} / \mathrm{s}$ (CDM/Limnetics, 1977) (fig. 3). Water flows from the north end of Silver Lake over a small dam (crest elevation $999.27 \mathrm{ft}$ above sea level) into Silver Creek (John Behrens, Silver Lake Sewer District, written commun., 2001). All references to datum altitude or lake stage are based on the National Geodetic Vertical Datum of 1929. Flow from Silver Lake measured during February to December 1977 ranges from 0.7 to $5.2 \mathrm{ft}^{3} / \mathrm{s}$ (CDM/Limnetics, 1977) (fig. 3). Monthly staff-gage measurements during 1977 


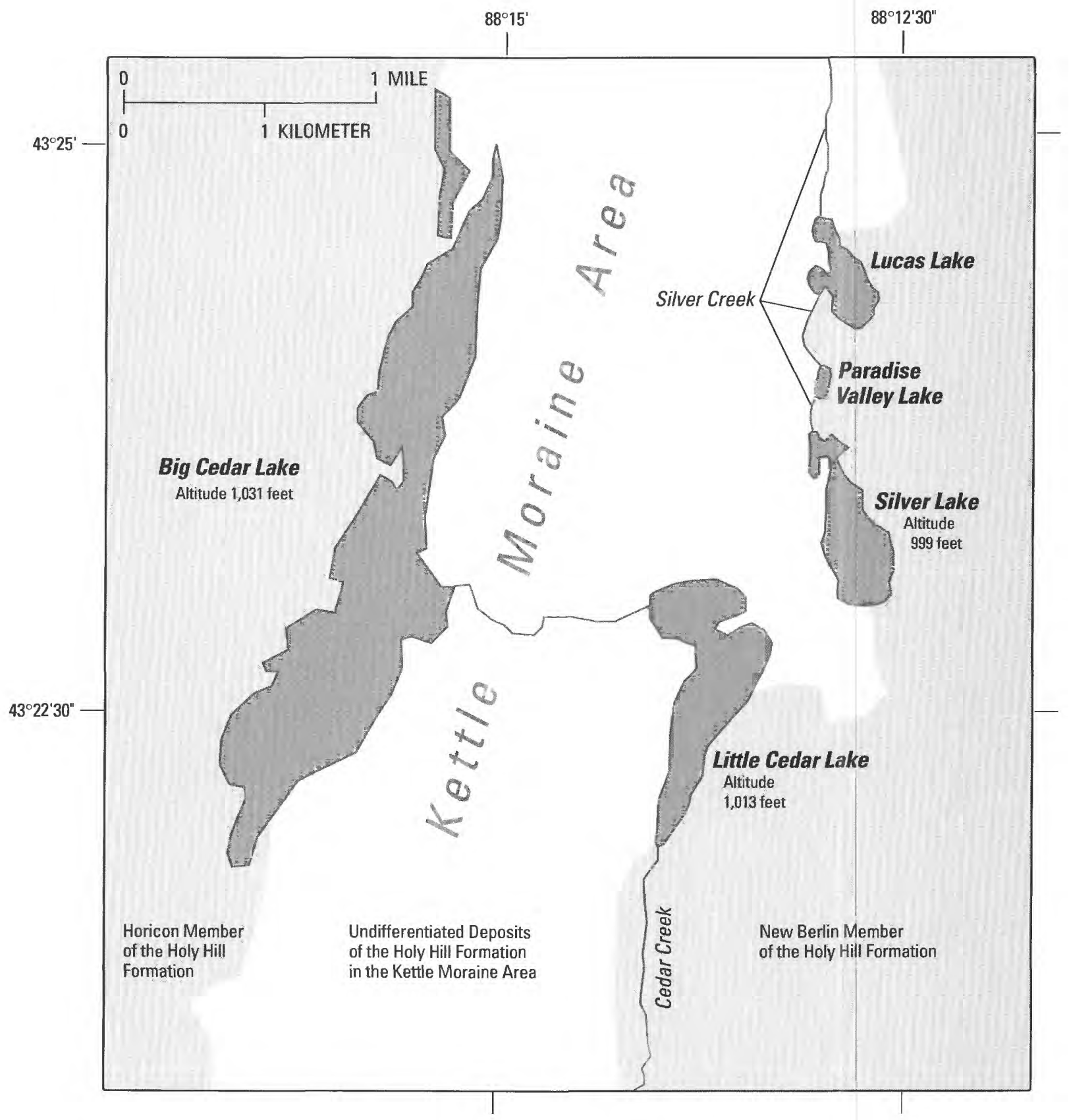

Figure 2. Lakes, creeks, and glacial stratigraphy of the Silver Lake study area, Washington County, Wisconsin (stratigraphy after Mickelson and Syverson, 1997). 
Table 1: Summary of analytical results for water-quality samples from Silver Lake and other lakes in southeastern Wisconsin

[mg/L, milligrams per liter; $\mu \mathrm{S} / \mathrm{cm}$, microsiemens per centimeter; $\mathrm{CaCO}_{3}$, calcium carbonate; -, no reported values; >, greater than]

\begin{tabular}{|c|c|c|c|c|}
\hline Reference & $\begin{array}{l}\text { Phosphorus } \\
\text { (mg/L) }\end{array}$ & $\begin{array}{l}\text { Chloride } \\
\text { (mg/L) }\end{array}$ & $\begin{array}{l}\text { Total alkalinity as } \mathrm{CaCO}_{3} \\
(\mathrm{mg} / \mathrm{L})\end{array}$ & $\begin{array}{c}\text { Specific conductance } \\
(\mu \mathrm{S} / \mathrm{cm})\end{array}$ \\
\hline CDM/Limnetics, $1977^{\mathrm{a}, \mathrm{b}}$ & $0.010-0.057^{\mathrm{c}}$ & $9.0-13.9$ & $193-293$ & $250-520$ \\
\hline Poff and Threinen, 1962 & - & $6.1-8.2^{d}$ & $194,202^{\text {a.e }}$ & $355,365^{\text {a.e }}$ \\
\hline Shaw and others, $1986^{f}$ & $0.010-0.040$ & $>10$ & $>180$ & - \\
\hline $\begin{array}{l}\text { U.S. Geological Survey, 1996; } \\
\text { U.S. Geological Survey, } 1997^{\text {a }}\end{array}$ & $0.005-0.102^{c}$ & 19 & 240 & $442-598$ \\
\hline
\end{tabular}

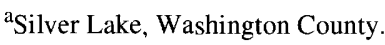

${ }^{\mathrm{b}}$ Sampled on an approximately monthly basis from March 29, 1976, through January 19. 1977. Sampled at surface and every 10 feet to 40 feet of depth.

${ }^{\mathrm{c}}$ Greater values are from samples just above bottom sediments.

${ }^{\mathrm{d}}$ Pike Lake, Washington County (8 miles southwest of Silver Lake).

'Two data points.

${ }^{f}$ Lakes of southeastern Wisconsin, original data are from Lillie and Mason, "Limnological Characteristics of Wisconsin Lakes", 1983.
}

show lake stage varies over $0.23 \mathrm{ft}$ (CDM/Limnetics, 1977) (fig. 3). Daily stage measurements during 2000 show a low lake stage of $999.30 \mathrm{ft}$ and a high lake stage of $999.50 \mathrm{ft}$ (John Behrens, Silver Lake Sewer District, written commun., 2001). The shoreline of Silver Lake is almost entirely developed with vacation and year-round homes. Ground water from the shallow aquifer is the primary source of domestic and municipal water supply in the area.

Precipitation that infiltrates through the ground to the water table is called recharge. Factors that affect the average annual recharge to the shallow aquifer in the Silver Lake study area include depth of precipitation, land cover, topography, and aquifer lithology. Recharge is estimated to vary greatly across the Washington County area-from a high of $12 \mathrm{in} / \mathrm{yr}$ to zero recharge in discharge areas such as wetlands (Douglas Cherkaur, University of Wisconsin-Milwaukee, written commun., 2001).

Lake chemistry in southeastern Wisconsin is described in Surface Water Resources of Washington County by Poff and Threinen (1962), and Understanding Lake Data by Shaw and others (1986). A study was conducted specifically for Silver Lake by CDM/Limnetics and included water chemistry analyses for samples collected from March 1976 to January 1977 (CDM/Limnetics, 1977). In addition, the USGS sampled and analyzed water from Silver Lake during 1996 and 1997. Selected data from these four sources are summarized in table 1. Data from the USGS sampling and analysis are included in the appendix.

Phosphorus, often the limiting nutrient for algae and weed growth in lakes, can have various anthropogenic sources including septic systems and fertilizer run-off (Shaw and others, 1986). Wisconsin lakes generally have phosphorus concentrations between 0.010 and $0.040 \mathrm{mg} / \mathrm{L}$ (Lillie and Mason, 1983). Average phosphorus concentrations equal to or less than $0.025 \mathrm{mg} / \mathrm{L}$ suggest good water quality, whereas phosphorus concentrations in excess of $0.055 \mathrm{mg} / \mathrm{L}$ suggest poor water quality (Lillie and Mason, 1983). Silver Lake phosphorus data (table 1) indicate a range from 0.005 to $0.102 \mathrm{mg} / \mathrm{L}$ (CDM/Limnetics, 1977; USGS, 1997 and 1998); however, the greatest concentrations usually are associated with samples taken immediately above the lake-bottom sediments and may not represent general lake water quality.

Chloride is not found naturally in Wisconsin ground water except where carbonate rocks are present. Chloride concentrations measured in Silver Lake (table 1) range from 9.0 to $19.0 \mathrm{mg} / \mathrm{L}$ (CDM/Limnetics, 1977; U.S. Geological Survey, 1997 and 1998), and are consistent with values typically found in southeastern Wisconsin (Shaw and others, 1986).

Alkalinity values in excess of $180 \mathrm{mg} / \mathrm{L}$ are considered to represent very hard water and result in the precipitation of marl $\left(\mathrm{CaCO}_{3}\right)$ (Shaw and others, 1986). Silver Lake is considered to be a hard lake (table 1), as are Big Cedar Lake, Little Cedar Lake, Lucas Lake and 


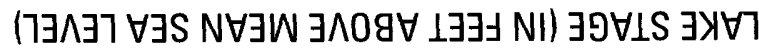

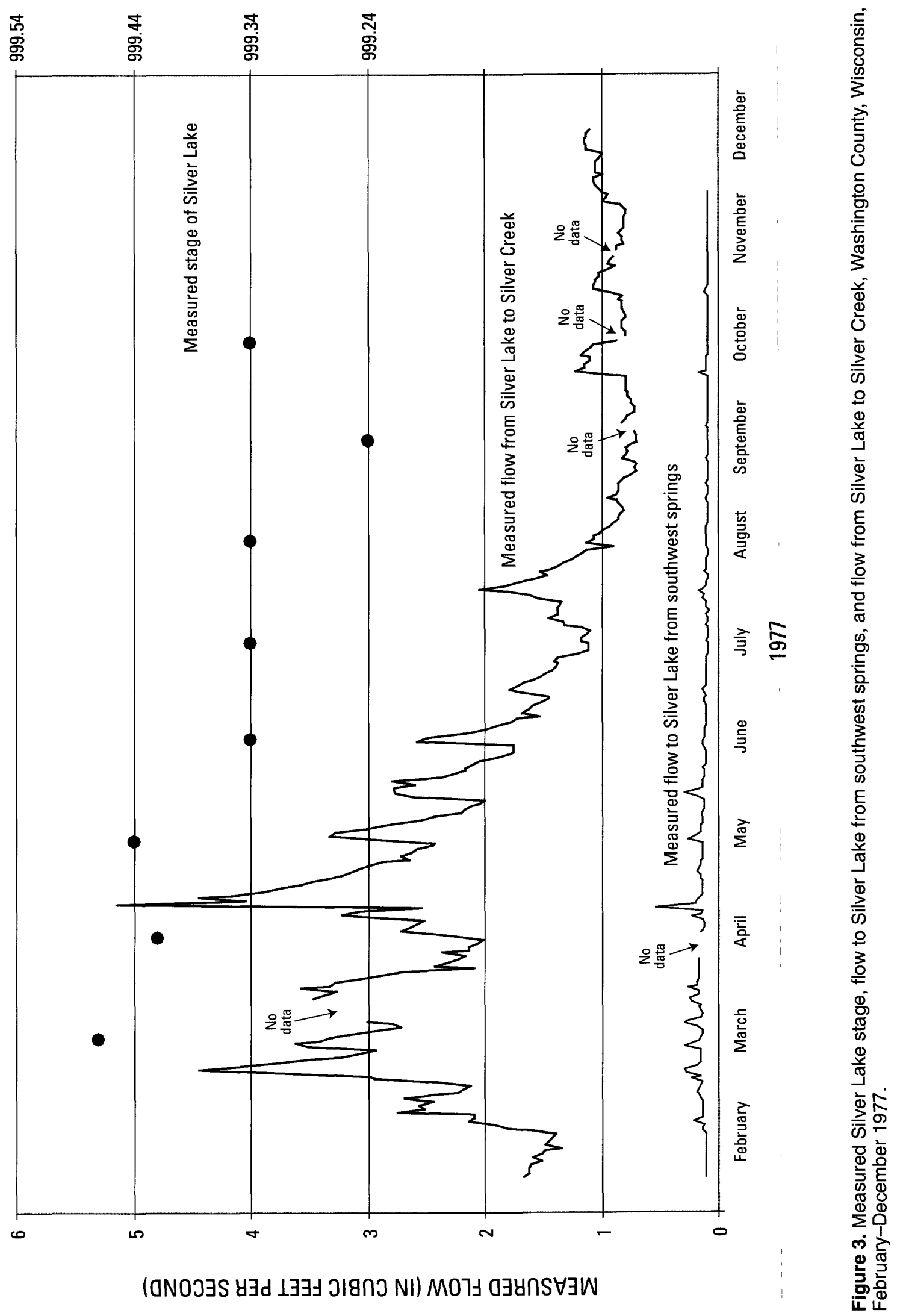


Paradise Valley Lake (Poff and Threinen, 1962). Marl formation often is considered beneficial because phosphorus precipitates along with $\mathrm{CaCO}_{3}$, thereby reducing the amount of this limiting nutrient available for algae blooms (Shaw and others, 1986).

Specific conductance is a measure of the ability of water to transmit an electrical current and is associated with the concentration of organic and inorganic solutes (Water Quality Association, 1999). Because many of these organic and inorganic ions are necessary for the growth of plants and algae, specific conductance can be used as an indirect measure of lake fertility (Poff and Threinen,1962). Reported specific conductance values in Silver Lake range from 250 to $598 \mu \mathrm{S} / \mathrm{cm}$ (table 1).

\section{Acknowledgments}

The authors would like to acknowledge the contributions of the following people and organizations. The Board of Commissioners of the Silver Lake Protection and Rehabilitation District supported the objectives of the study, and two commissioners, Gary Coates and John Behrens, assisted with site visits and collection of various data used in the study. Jeffrey Thornton of the Southeast Wisconsin Regional Planning Commission provided assistance in establishing the scope of the investigation and setting the work into the larger framework of southeastern Wisconsin. James Rauman and Bernard Ellefson of the USGS installed lake stage and precipitation instruments on the shoreline of Silver Lake. Madeline Gotkowitz of the Wisconsin Geologic and Natural History Survey and Michael Merrit of the USGS provided technical review of the report. Gail Moede of the USGS provided editorial review of the report. Jim Krohelski and Randy Hunt of the USGS provided invaluable assistance with many aspects of the study including review of conceptual models and the analytic-element model.

\section{METHODS}

An analytic-element (AE) ground-water-flow model was developed for the Silver Lake study area to simulate shallow ground-water flow and its interaction with surface-water features. The AE model, developed with the use of the computer program GFLOW (Haitjema, 1995), is a single-layer, steady-state model, in which the aquifer is assumed to be infinite. The AE model makes use of the Dupuit-Fochheimer approxima- tion which assumes ground-water flow in the single layer is horizontal. This approximation is valid when the aquifer is thin relative to its extent, as is the case in the Silver Lake study area.

Important hydrologic features are represented in the AE model domain as analytic elements or strings of analytic elements (line-sinks). Each element provides a solution to the ground-water-flow equation, and the additive effect of many individual solutions (superposition) is a solution for ground-water flow. Because a solution for ground-water flow can be evaluated at any point in the model domain, AE models do not make use of model cells or a grid. Regional values for aquifer parameters and rate of recharge are applied across the entire AE model domain. The model domain comprises both a far-field and a near-field (fig. 4). The far-field is beyond the area of interest, but is included in the model to properly define hydrologic boundary conditions for the near-field. Far-field elements usually are coarsely defined and consist only of water-level information. The location and elevation of all surface-water features were estimated using USGS topographic data.

The near-field is the area of primary interest and contains any important local hydrologic inhomogeneities, that is, areas where recharge and/or aquifer parameter values differ appreciably from regional values. A hydrologic inhomogeneity can be represented in the $\mathrm{AE}$ model as an area defined by model elements within which the non-regional parameter values are present. Near-field analytic elements are more precisely defined than those in the far-field. Specifically, near-field elements have more line-sink vertices (and, therefore, solutions) and contain information on the width and resistance of the represented feature (Strack, 1989; Haitjema, 1995; Hunt and Krohelski, 1996; Hunt and others, 1998). Silver Lake is represented in the AE model as a line-sink lake using the lake package in GFLOW, and as such, width and resistance parameters account for lake-bottom resistance (Henk Haitjema, Haitjema consultants, written commun. to Wisconsin Department of Natural Resources, March, 2002). The head along the element is constant (the lake stage) and will be determined iteratively during the solution process. Net precipitation on the lake is defined by adding an inhomogeneity representing evaporation. The GFLOW lake package has been shown to provide results similar to the MODFLOW lake package (LAK1) for lakes in northern Wisconsin (Hunt and others, written commun., 2001). 
(a) Far-field

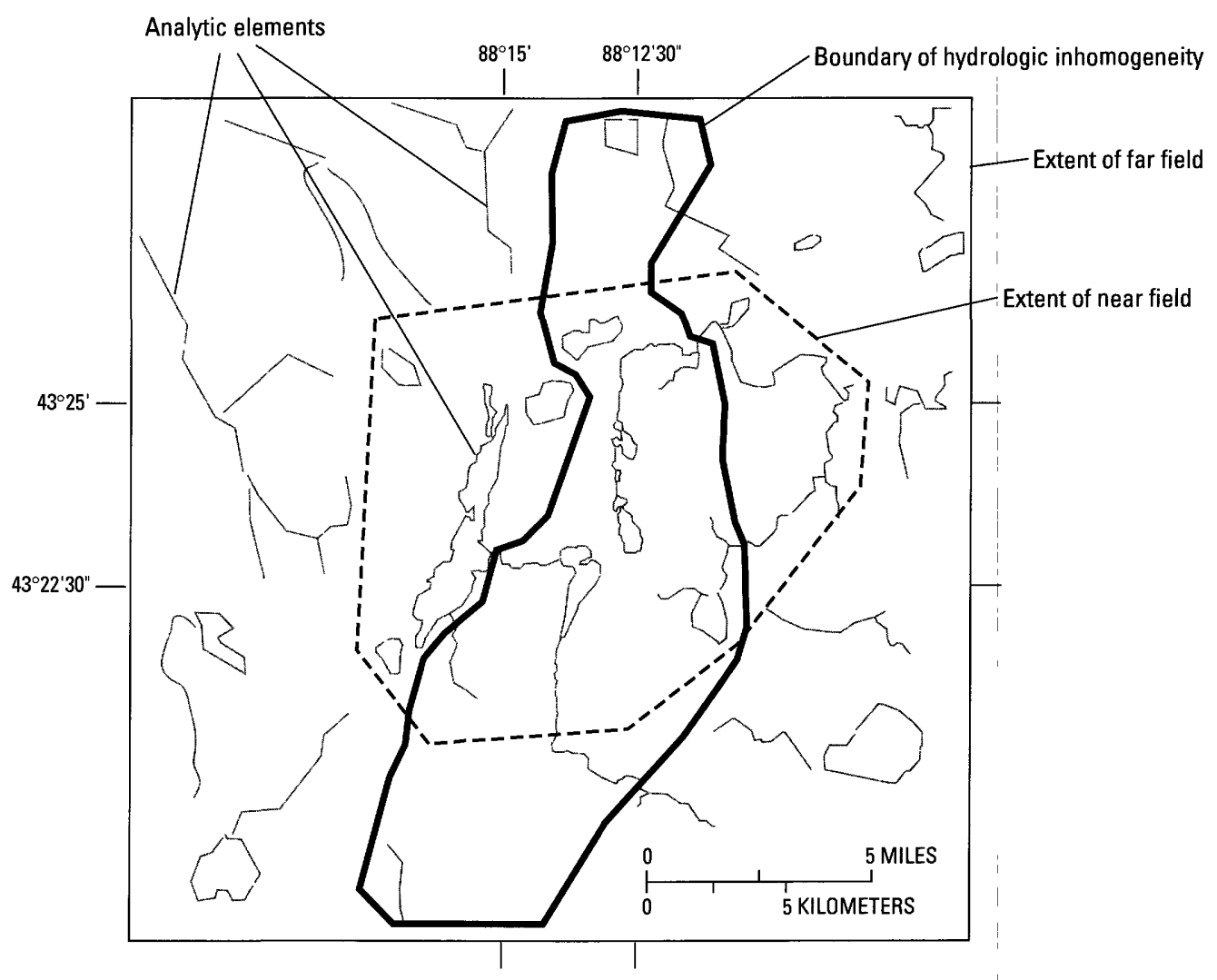

(b) Near-field

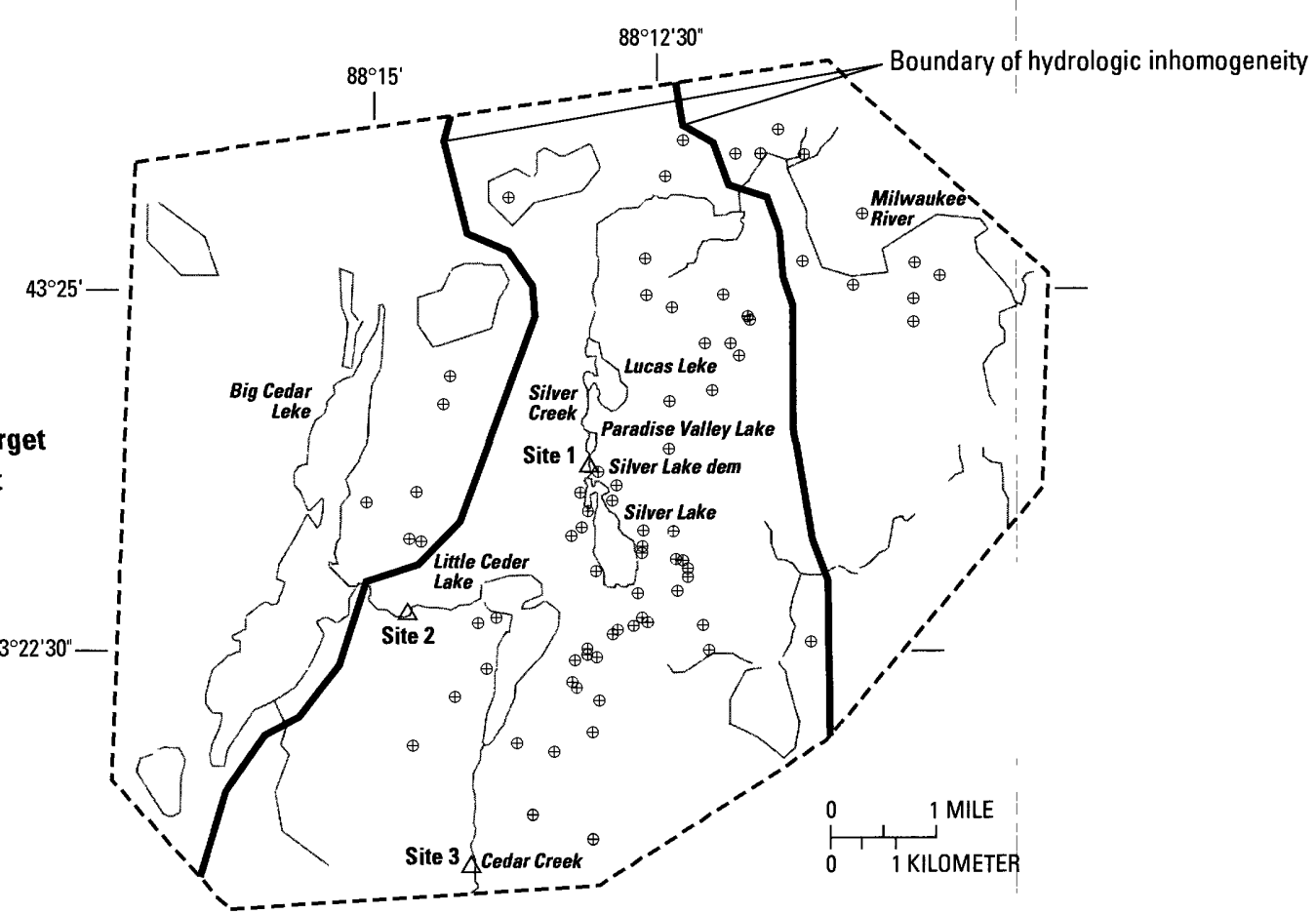

Figure 4. Analytic elements and calibration targets in the Silver Lake model area, Washington County, Wisconsin, (a) far-field, (b) near-field. 
Calibration of the AE model was performed through trial-and-error changes to hydrologic parameters to minimize the difference between simulated and measured hydraulic heads, and simulated and measured streamflows. Whereas it would be ideal for all head and streamflow targets for a model to have been measured at the same instant in time, and for conditions during those measurements to reflect the long-term average conditions, this is rarely the case. In this study, the available data had been collected over many years, and represent different seasons as well as different conditions (relatively wet or dry years).

Hydraulic-head targets are static (non-pumping) water-level elevations measured in wells within the near-field of the AE model. Head targets used for calibrating the Silver Lake AE model came from three sources: the USGS Ground-Water Site Inventory (GWSI) database, the Wisconsin Department of Natural Resources Groundwater Retrieval Network (GRN), and the CDM/Limnetics report (1977). These data were sorted and selected to identify a final set of head targets.

The GRN database contains construction information for water-supply wells, including measured static water level (head). Many wells were found in the nearfield of the Silver Lake model domain. The number of wells was reduced to a manageable 35 by using wells constructed over 3 consecutive and recent water years, 1992, 1993, and 1994, a time during which many new wells were constructed. Because GRN wells are located only by quarter/quarter section, each well was located more precisely within the model domain, when possible, by using the street address, and topographic and plat maps.

The GWSI database contained 308 wells for Washington County. Forty-five of these wells, located by latitude and longitude, fell within the near-field study area and are included as head targets. Dates for these head data range from 1930 to 1993 . Eight wells close to Silver Lake were selected from the CDM/Limnetics report and included as head targets. These head data are all from 1976 and 1977. From the three sources, 88 nearfield head targets were identified to be used for model calibration.

The only historical measurements of streamflow found for the study area were for Silver Creek immediately downstream of Silver Lake dam (CDM/Limnetics, 1977) (site 1, fig. 4, table 2). As part of this study, additional measurements were made at that location. Flow measurements also were made at two new locations: on the creek between Big Cedar and Little Cedar Lakes, and about $0.6 \mathrm{mi}$ downstream of Little Cedar Lake (sites 2 and 3, fig. 4, table 2). Streamflow was measured using a Pygmy current meter and standard USGS methods (Rantz and others, 1982). Base-flow conditions (approximately steady-state) were inferred from historical measurements of Silver Creek below Silver Lake (fig. 3) (CDM/Limnetics, 1977), and flow measured at the other two locations was believed to be base flow based on comparison to historical records of the nearby Milwaukee River gage in Cedarburg.

Table 2. Measured and simulated streamflow, Washington County, Wisconsin

[values in cubic feet per second]

\begin{tabular}{lccc}
\hline \multicolumn{1}{c}{ Location } & $\begin{array}{c}\text { Site } \\
\text { number }\end{array}$ & Observed & Simulated \\
\hline Below Silver Lake & 1 & 0.7 to $5.2^{\mathrm{b}}$ & $1.24^{\mathrm{c}}$ \\
$\begin{array}{c}\text { Between Big Cedar } \\
\text { and Little Cedar Lakes }\end{array}$ & 2 & $11.4^{\mathrm{d}}$ & 9.5 \\
$\begin{array}{c}\text { Cedar Creek at } \\
\text { Pleasant Valley Rd }\end{array}$ & 3 & $13.2^{\mathrm{d}}$ & 13.0 \\
\hline
\end{tabular}

asites shown on figure $4 b$.

bMeasurements taken on July 27, 2000, September 14, 2000 and November 21, 2000.

${ }^{\mathrm{c}}$ Calculated as residual in water balance.

${ }^{\mathrm{d}}$ Measurement taken on November 21, 2000.

\section{DEVELOPMENT OF THE ANALYTIC- ELEMENT MODEL}

To simulate ground-water flow in the Silver Lake study area, hydrologic features and aquifer properties must be identified in a conceptual model. Development of the AE model is based on the conceptual model that represents those important hydrologic features. Once the AE model is calibrated to hydraulic-head and streamflow targets, it can be used to simulate shallow ground-water flow in the study area.

\section{Conceptualization}

A conceptual model of the study area was developed to establish a framework for AE model development (fig. 5). The shallow aquifer is composed of laterally extensive, unconsolidated glacial deposits of the Holy Hill Formation. These deposits primarily are stratified sand and gravel, and range in thickness across 


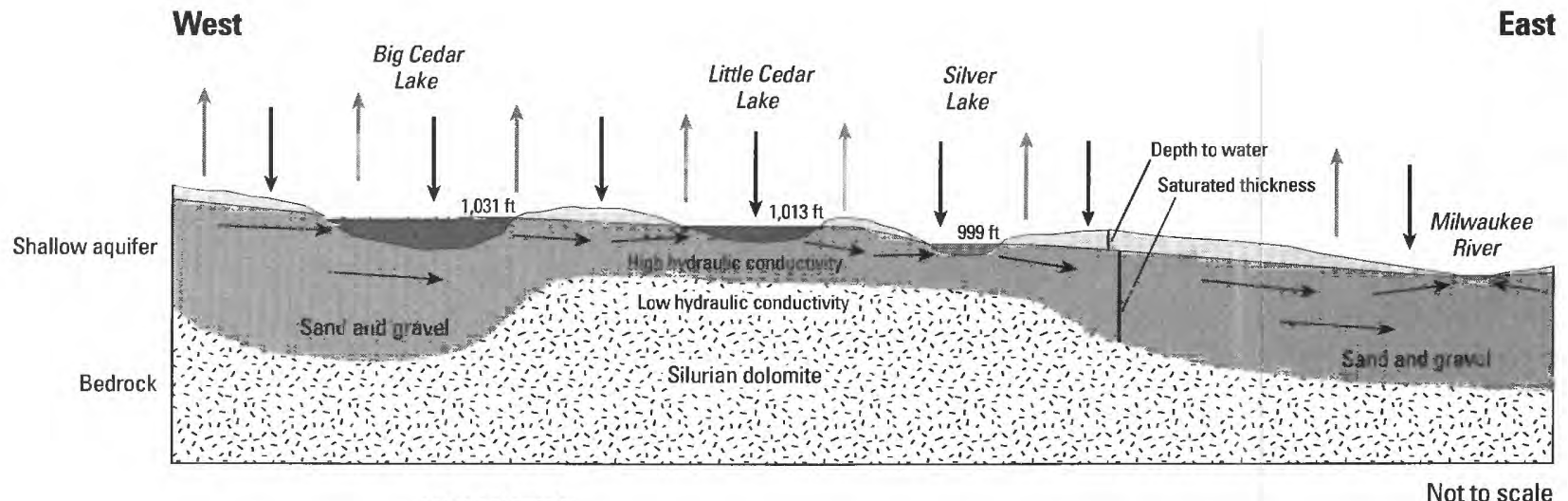

EXPLANATION

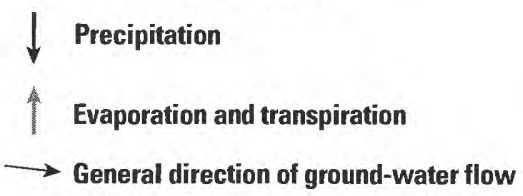

Figure 5. Conceptual model, in cross-sectional view, of the interaction of lakes, precipitation, evaporation, and shallow ground-water flow in the vicinity of Silver Lake, Washington County, Wisconsin.

the study area from 100 to $300 \mathrm{ft}$ (Mickelson and Syverson, 1997). Although the underlying Silurian dolomite bedrock can be a productive aquifer, its hydraulic conductivity (about $0.6 \mathrm{ft} /$ day) is much less than the overlying unconsolidated sand and gravel (Mickleson and Syverson, 1997; Poff and Threinen, 1962). Therefore, the highly transmissive glacial sediments are considered to be an aquifer bounded on the bottom by low transmissivity bedrock. The irregularity of the bedrock surface and the hilly terrain of the Kettle Moraine result in a shallow aquifer with a variable saturated thickness across the study area. The hilly terrain also results in variable depth to ground water across the study area (fig. 5).

The depth of Silver Lake and the thickness and character of the shallow aquifer determine whether Silver Lake captures all the upgradient water flowing toward it, or if some will flow underneath the lake. The maximum and mean depths of Silver Lake are about $45 \mathrm{ft}$ and $20 \mathrm{ft}$, respectively (Poff and Threinen, 1962). The shallow aquifer generally is about $100 \mathrm{ft}$ thick around Silver Lake, though it varies substantially, from about 50 to about $200 \mathrm{ft}$ (Mickleson and Syverson, 1997). Flow-through seepage (that is, lakes that receive ground-water discharge on one side, and recharge the aquifer on the opposite side) becomes more prevalent as the length of the lake parallel to mean ground-water flow direction increases relative to the aquifer thickness (Nield and others, 1994). Lower aquifer anisotropy (ratio of horizontal to vertical hydraulic conductivity) and lower lake-bed resistance also favor flow-through seepage. The shallow aquifer under Silver Lake is relatively thin (about $100 \mathrm{ft}$ ) compared to the east-west distance across the Lake (about 1,400 ft). Whereas there are no specific data on aquifer anisotropy or lake-bed resistance, the presence of springs on the western shore indicates that the lake is a discharge area. These conditions suggest that it is likely most of the upgradient water flowing toward Silver Lake will be captured and little will flow underneath.

The shallow aquifer is recharged by precipitation (minus interception and evapotranspiration) that falls across the study area. Ground water moves from topographically high areas to topographically low areas (higher potential to lower potential). Therefore, ground water generally moves toward surface-water features in topographic lows. Because of the strong hydraulic connection between the lakes and ground water, the conceptual model suggests water flows through the shallow aquifer from Big Cedar Lake (stage is about 1,031 ft) to Little Cedar Lake (stage is about 1,013 ft) to Silver Lake (stage is about $999 \mathrm{ft}$ ) (figs. 2 and 5). It is likely that 
Silver Lake receives ground water on its western, upgradient side, and contributes to ground water on its eastern, downgradient side. In addition, because Silver Lake is the headwater for Silver Creek, some of the ground water that flows into Silver Lake on the west flows north out of the lake to Silver Creek. Lake stage and flow to Silver Creek is controlled by a fixed elevation dam; therefore, lake storage (volume) changes only slightly during the year.

In addition to ground-water flow into and out of the lake, other lake-budget components that were considered for Silver Lake are precipitation falling on the lake and evaporation from the lake surface (fig. 5). In this part of southeastern Wisconsin, annual precipitation on a free-water surface exceeds evaporation from that surface by about $3 \mathrm{in} / \mathrm{yr}$ (Novitzki, 1982). Overland flow of precipitation to Silver Lake was not considered to be an important component of the hydrologic budget because of the permeable nature of the sand and gravel deposits -infiltration will likely always exceed precipitation.

\section{Construction}

Based on the conceptual model and preliminary parameter optimization using the optimization code UCODE (Poeter and Hill, 1998), regional values were chosen for recharge ( $4 \mathrm{in} / \mathrm{yr}$ ), average horizontal hydraulic conductivity ( $50 \mathrm{ft} / \mathrm{day}$ ), and base elevation of the aquifer across the model $(800 \mathrm{ft})$. An area within the model domain in which hydrologic parameter values are different appreciably from the regional values is a hydrologic inhomogeneity. A single hydrologic inhomogeneity was added to the model (fig. 4a). The shape of this inhomogeneity and its values represent an area with appreciably different model base elevation, and possibly hydraulic conductivity and recharge for the Kettle Moraine Area that trends through central Washington County (fig. 2).

The near-field of the AE model contains analytic elements (line sinks) that represent hydrologic features of primary interest, including Silver Lake, Silver Creek, Big Cedar and Little Cedar Lakes, Cedar Creek, Paradise Valley Lake, Lucas Lake, and portions of the Milwaukee River, as well as some surrounding wetlands and streams (fig. 4b). In the near-field, model elements have attributes of width and resistance. The model elements were assigned widths that best represent the feature. For example, streams were assigned widths of 3 to $10 \mathrm{ft}$, the Milwaukee River was assigned widths of 25 to
$100 \mathrm{ft}$, and lakes were assigned widths of 25 to $500 \mathrm{ft}$ (table 3). Resistance is a measure of how difficult it is for water to move between surface-water features and the shallow aquifer. All near-field streams and rivers were assigned a value of $0.5 \mathrm{ft} / \mathrm{ft} /$ day for resistance, and lakes were assigned a value of $1.0 \mathrm{ft} / \mathrm{ft} /$ day (table 3 ).

Table 3. Resistance and width of lakes and streams in the Silver Lake, Washington County, Wisconsin, analytic-element model

\begin{tabular}{lcc}
\hline $\begin{array}{c}\text { Surface-water } \\
\text { feature }\end{array}$ & $\begin{array}{c}\text { Resistance }^{\text {a }} \\
\text { (in days) }\end{array}$ & $\begin{array}{c}\text { Width } \\
\text { (in feet) }\end{array}$ \\
\hline Big Cedar Lake & 1.0 & 500 \\
Little Cedar Lake & 1.0 & 100 \\
Silver Lake & 1.0 & 100 \\
Paradise Lake & 1.0 & 25 \\
Lucas Lake & 1.0 & 25 \\
& & \\
Silver Creek & .5 & 3 \\
Silver Creek to & .5 & 5 \\
$\quad$ Milwaukee River & & 10 \\
Stream from Big Cedar & .5 & 10 \\
$\quad$ to Little Cedar Lake & & \\
Cedar Creek & .5 & 25 or 100 \\
Milwaukee River & .5 &
\end{tabular}

${ }^{a}$ Resistance is thickness of lake or stream bottom sediments (feet) divided by their hydraulic conductivity (feet per day)

Silver Lake was unique among the lakes in the model in that it was represented by a lake-specified element, and as such provided a steady-state simulation of Silver Lake stage by iterating to a balance of net precipitation on the lake, ground-water inflow and outflow, and surface-water outflow (Hunt and others, in press). Parameters specified for this lake element include the bottom elevation of Silver Lake (defined as $975 \mathrm{ft}$ ), resistance (defined as $1 \mathrm{ft} / \mathrm{ft} /$ day), and net precipitation on the lake (total precipitation minus evaporation defined as $3 \mathrm{in} / \mathrm{yr}$ ). In addition, measured spring flow of $0.1 \mathrm{ft}^{3} / \mathrm{s}$ from the southwest end of the lake was added as overland flow to the lake distributed uniformly along the lake element. Also defined in the model is the relation between lake stage and lake area, and lake stage and outflow over the Silver Lake Dam. Lake area was considered to be a constant $5,122,656 \mathrm{ft}^{2}(117.6 \mathrm{ac})$ over the relatively small range of stage change. The relation between lake stage and outflow was derived from monthly lake stage and daily flow measurements taken 
during 1977 (fig. 3) (CDM/Limnetics, 1977) adjusted for recent survey information at the dam (John Behrens, Silver Lake Sewer District, written commun., 2001). Based on this relation, outflow to Silver Creek ranges from 0.8 to $3.3 \mathrm{ft}^{3} / \mathrm{s}$ for a range of stages 999.34 to $999.57 \mathrm{ft}$ (table 4). Therefore, with lake bottom elevation and resistance specified, net precipitation on the lake specified, and the lake area/stage and lake outflow/stage relations specified, the calibrated model simulates a steady-state lake stage that is in balance with discharge from the aquifer to the lake and recharge from the lake to the aquifer.

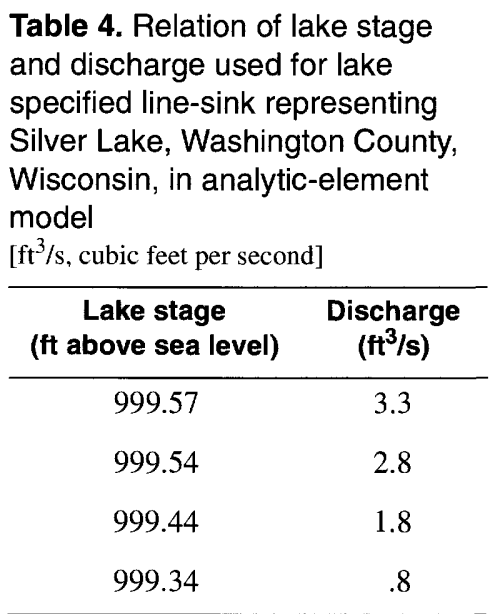

\section{Calibration}

Calibration of the AE model was performed through trial-and-error changes to hydrologic parameters to minimize the difference between simulated and measured heads and streamflows. Regional values for recharge and hydraulic conductivity were varied, as were values for recharge, hydraulic conductivity, and base elevation within the inhomogeneity. Recharge values were varied between $2 \mathrm{in} / \mathrm{yr}$ and $18 \mathrm{in} / \mathrm{yr}$, hydraulic conductivity values were varied over two orders of magnitude from $1 \mathrm{ft} /$ day to $100 \mathrm{ft} / \mathrm{day}$. The shape of the inhomogeneity also was varied though kept generally coincident with the Kettle Moraine Area shown in figure 2.

Following calibration of the Silver Lake AE model, the match of simulated heads to measured heads generally was good. In figure 6 , triangles represent these results at target locations. An upward-pointing triangle indicates that the model simulated a head greater than measured at a given target location, and a downward- pointing triangle indicates that the model simulated a head lower than measured. Targets simulated high and those simulated low are found distributed across the model. The lack of clustering of high- or low-modeled targets indicates the model is relatively accurate across the entire domain. Additional evidence that the model simulation reasonably represents shallow ground-water flow is the scatter plot comparing simulated heads to measured heads (fig. 7) showing a good correlation with scatter on both sides of the line of perfect agreement. Calibration statistics for these 88 head targets also are presented in figure 7 . The maximum difference between simulated and measured heads was $35.8 \mathrm{ft}$ greater and $50.9 \mathrm{ft}$ less than measured. The average difference (AD) between simulated and measured heads was $-0.2 \mathrm{ft}$, and the mean difference was $-1.5 \mathrm{ft}$. The mean absolute difference (MAD) is the mean of the absolute values of the differences in simulated and measured heads, and is $10.8 \mathrm{ft}$ for the calibrated model. The root mean squared (RMS) difference is the square root of the average of the squared differences in simulated and measured heads, and is $14.7 \mathrm{ft}$. The value of calibration criteria that is acceptable is subjective, but can be evaluated on the basis of the change in heads over the model domain. For instance, if the ratio of the RMS difference to the head difference across the model domain is small, the errors represent a small part of the overall model response (Anderson and Woessner, 1992). For the Silver Lake model, measured heads range over almost $200 \mathrm{ft}$, as compared to the RMS difference of 14.7 , resulting in a relatively small ratio. The calibrated model also accurately simulated measured streamflow at the three locations (fig. 4 and table 2); however, it is a small streamflow data set. If additional measurements at these sites or measurements at additional sites provide more precise steady-state flow data, recalibration of the model may be warranted.

The calibrated values for global recharge and hydraulic conductivity did not change from their initial values (4 in/yr recharge and $50 \mathrm{ft} /$ day hydraulic conductivity). Calibrated values for the inhomogeneity were $12 \mathrm{in} / \mathrm{yr}$ for recharge and $20 \mathrm{ft} /$ day for hydraulic conductivity. In addition, the model base was raised from 800 to $900 \mathrm{ft}$ in the inhomogeneity. This change in hydraulic conductivity and model base elevation represents a 4- to 5-fold reduction in transmissivity in the area represented by the inhomogeneity. All simulations discussed in the following section of the report use only these calibrated values. 


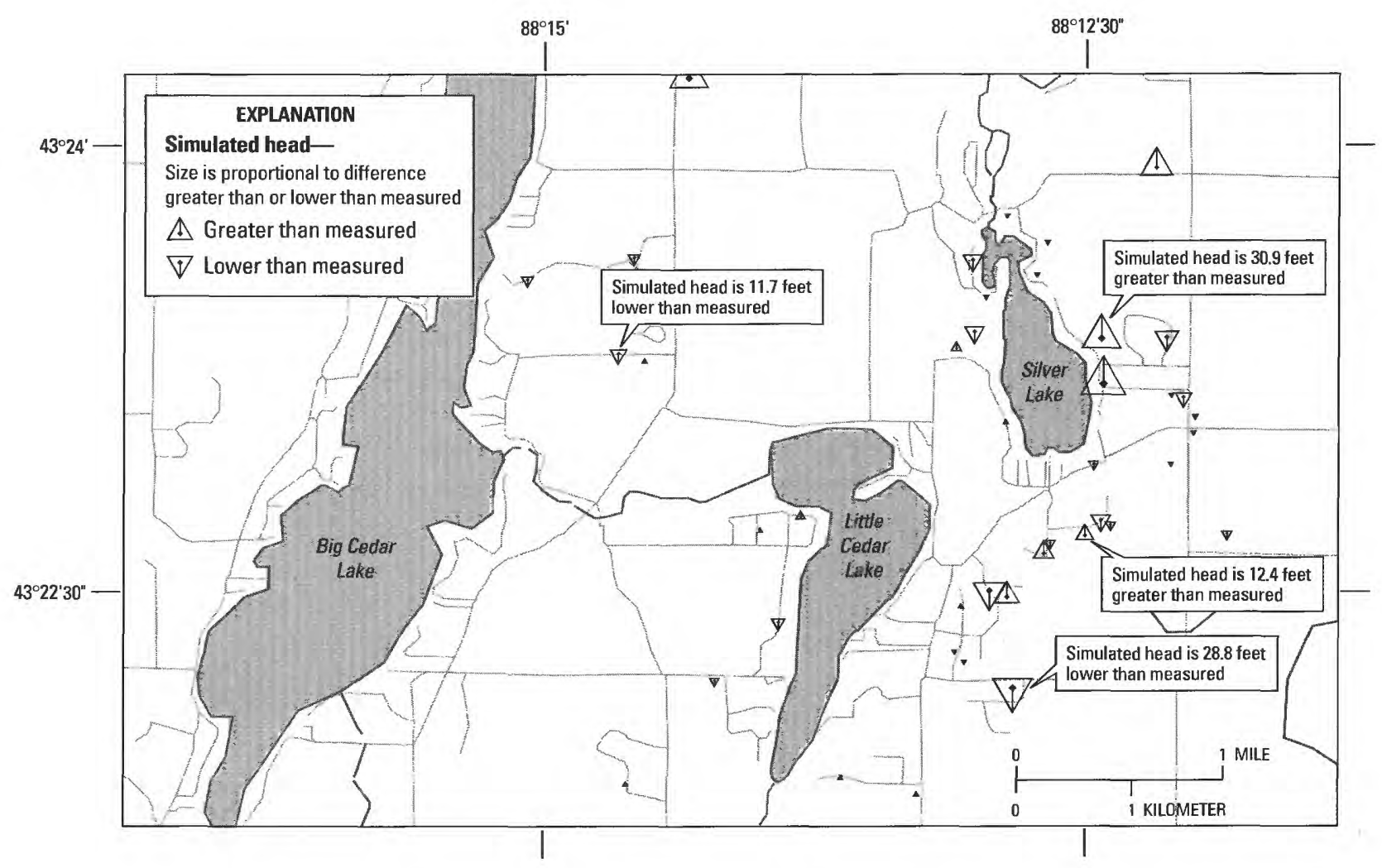

Figure 6. Comparison of simulated to measured head targets in the calibrated Silver Lake, Washington County, Wisconsin, analytic-element model.

During model calibration it was found that calibration to head targets was most sensitive to hydraulic conductivity and recharge values defined for the inhomogeneity, and less sensitive to global values. Conversely, calibration to streamflow sites 2 and 3 was sensitive primarily to global hydraulic conductivity and recharge (outside of the inhomogeneity). This sensitivity appears to be because streamflow at both sites depends appreciably on the flow coming from Big Cedar Lake, which lies outside the inhomogeneity.

\section{SIMULATION OF SHALLOW GROUND- WATER FLOW}

The calibrated AE model provides a simulated water table for the Silver Lake study area (fig. 8). The general ground-water flow direction is shown to be from west to east with lakes and streams affecting the regional pattern. The simulation also shows ground water discharging to Silver, Big Cedar, and Little Cedar Lakes over most of their upgradient (western) shorelines. The downgradient (eastern) sides of these lakes are shown to be recharging to ground water. Backward particle tracking from the bottom of the aquifer on the eastern, downgradient side of Silver Lake suggests that the lake captures almost all of the upgradient ground water through the entire aquifer thickness. A notable exception is the shallower and narrower north end of the lake where a greater proportion of particles are found to flow under the lake from west to east. Whereas the calibrated model can be used for general interpretive evaluation of the Silver Lake area, it also can be used to test potential changes affecting the watershed. For instance, the effect of a pumping well placed upgradient or downgradient of the lake could be simulated. Specific changes to ground-water recharge areas (such as adding impervious areas like parking lots) could be simulated. The model provides a tool for assessing the effect of a wide range of activities or land-management choices.

\section{Hydrologic Budget for Silver Lake}

Simulated ground-water flow provided by the AE model can be combined with reported precipitation and evaporation values for Silver Lake to estimate the steady-state surface-water flow from the lake to Silver 


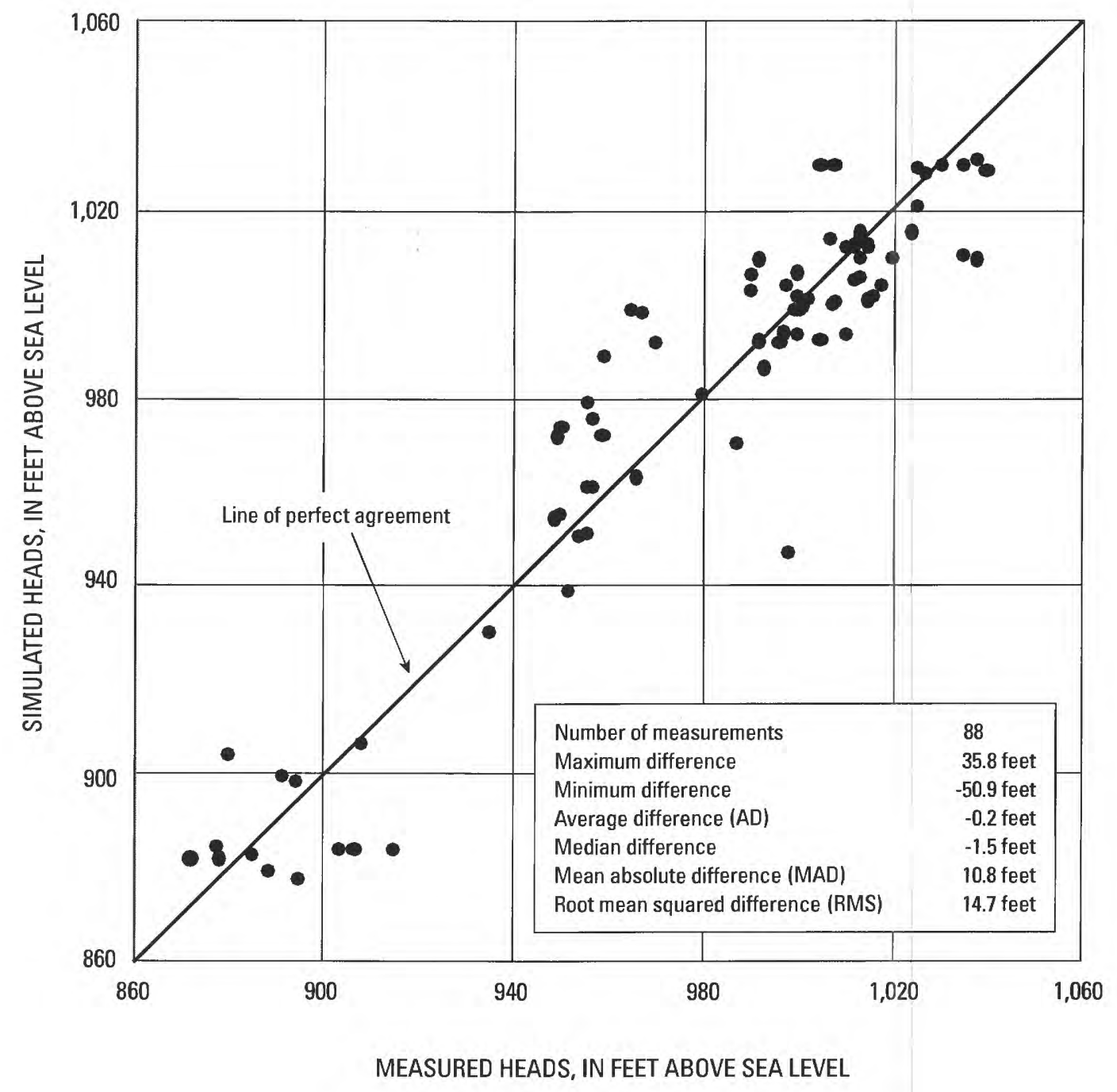

Figure 7. Scatter plot comparing simulated heads to measured heads for the calibrated Silver Lake, Washington County, Wisconsin, analytic-element model. 


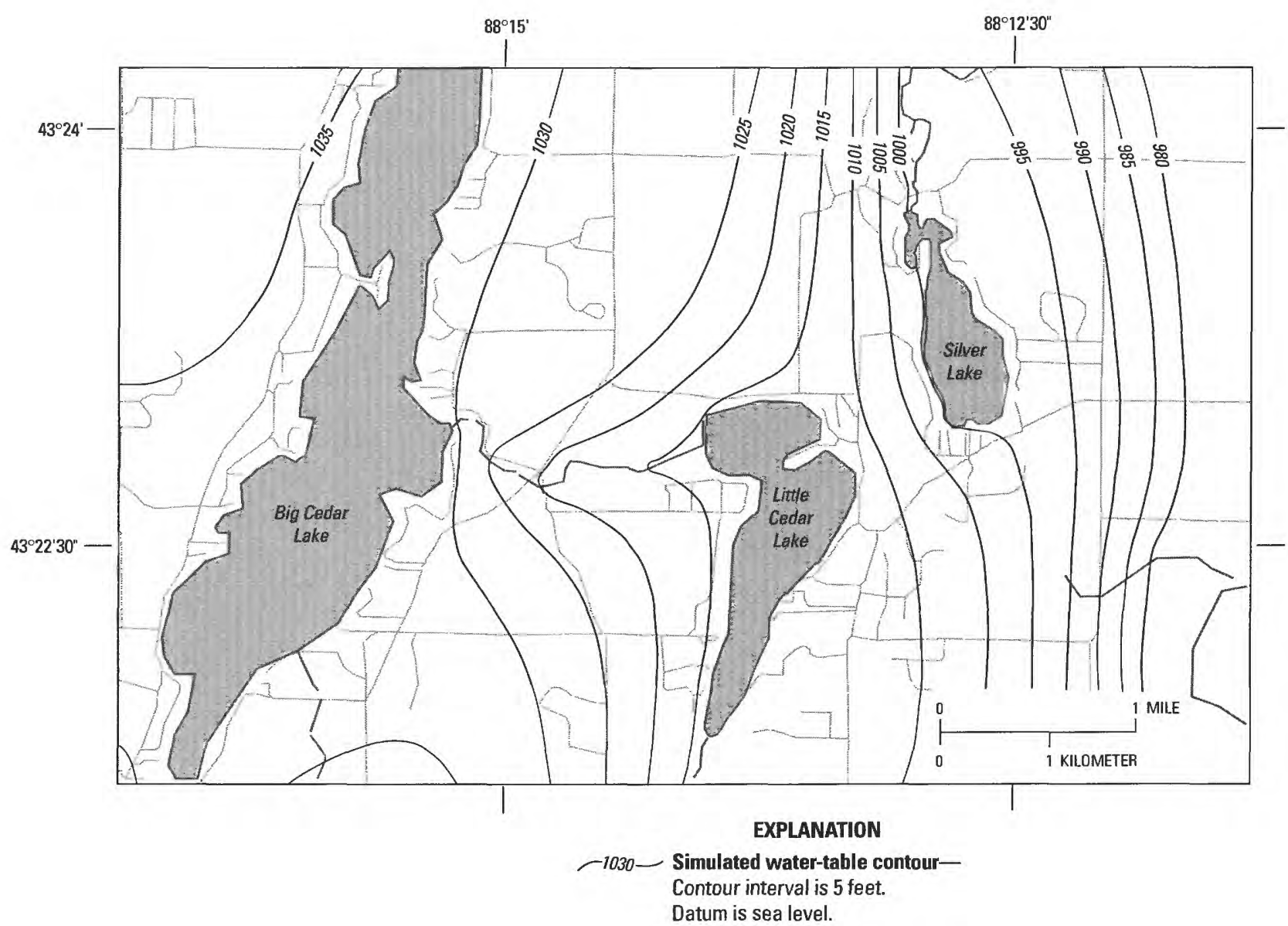

Figure 8. Simulated water table from the calibrated Silver Lake, Washington County, Wisconsin, analytic-element model.

Creek. Comparison of this estimated flow to measured values provides an additional calibration point to increase confidence in the $\mathrm{AE}$ simulation and its usefulness. A hydrologic budget for Silver Lake can be defined by the following equation and represented in figure 9.

$$
\Delta \mathrm{S}=\mathrm{P}-\mathrm{E}+\mathrm{GW}_{\text {in }}-\mathrm{GW}_{\text {out }}+\mathrm{SW}_{\text {in }}-\mathrm{SW}_{\text {out }},
$$

where

$\Delta S \quad$ is change in lake storage,

$\mathrm{P}$ is precipitation falling directly on the lake,

E is water evaporated from the lake surface,

$\mathrm{GW}_{\text {in }}$ is ground water discharging to the lake,

$\mathrm{GW}_{\text {out }}$ is lake water recharging ground water,

$\mathrm{SW}_{\text {in }}$ is surface-water flow to the lake, and

$\mathrm{SW}_{\text {out }}$ is flow out of the lake to Silver Creek.

The following assumptions and simplifications have been made:
- $\mathrm{GW}_{\text {in }}$ includes $0.10 \mathrm{ft}^{3} / \mathrm{s}$ measured spring flow into Silver Lake,

- there is no surface-water flow $\left(\mathrm{SW}_{\text {in }}\right)$ into Silver Lake,

- overland flow to Silver Lake is negligible, and

- lake storage does not change over time $(\Delta S=0)$, that is, ground-water flow is at steady state (lake stage, and, therefore, volume, is controlled by a dam).

Because $\Delta S$ and $S_{\text {in }}$ are assumed to equal zero, equation 1 can be rewritten as

$$
\mathrm{SW}_{\text {out }}=(\mathrm{P}-\mathrm{E})+\left(\mathrm{GW}_{\text {in }}-\mathrm{GW}_{\text {out }}\right)
$$

In the form given in equation 2, the flow from Silver Lake into Silver Creek $\left(\mathrm{SW}_{\text {out }}\right)$ is calculated as a residual in the hydrologic budget. Annual precipitation on the lake is about $3 \mathrm{in} / \mathrm{yr}$ greater than evaporation (Novitzki, 1982), that is, the term P minus E is $3 \mathrm{in} / \mathrm{yr}$. Considering the area of Silver Lake (117.6 ac), 3 in/yr is equal to $0.04 \mathrm{ft}^{3} / \mathrm{s}$. Based on calibrated model results, 
$\mathrm{GW}_{\text {in }}$ minus $\mathrm{GW}_{\text {out }}$ is $1.00 \mathrm{ft}^{3} / \mathrm{s}$. Therefore, streamflow out of Silver Lake ( $\mathrm{SW}_{\text {out }}$ ) is equal to the sum of the terms (P-E) and $\left(\mathrm{GW}_{\text {in }}-\mathrm{GW}_{\text {out }}\right)$ resulting in

$$
\mathrm{SW}_{\text {out }}=\left(0.04 \mathrm{ft}^{3} / \mathrm{s}\right)+\left(1.00 \mathrm{ft}^{3} / \mathrm{s}\right)=1.04 \mathrm{ft}^{3} / \mathrm{s}
$$

Streamflow from Silver Lake of $1.04 \mathrm{ft}^{3} / \mathrm{s} \mathrm{com-}$ pares well to new and historical measurements of streamflow from Silver Lake ranging from 0.7 to $5.2 \mathrm{ft}^{3} / \mathrm{s}$ (table 3 ). The higher end of this flow range likely represents flow over the dam during short-term elevated lake stages resulting from storm events. Because the AE model simulates steady-state conditions, that is, long-term average (baseflow) conditions, it more properly reflects the lower end of the range of measured streamflow. The water budget for Silver Lake is summarized in figure 9 .

\section{Ground-Water Recharge Areas for Silver Lake}

Activities in ground-water-recharge areas can have a direct effect on Silver Lake water quantity and quality. Delineation of recharge areas for ground water flowing to Silver Lake is important for the protection of the lake, and for making land-management decisions. Groundwater recharge areas for Silver Lake were simulated by using backward-particle tracking in the AE model. Mathematical water particles were placed at the bottom of the aquifer along the upgradient side of Silver Lake and tracked backward in time for 10,20 and 50 years (fig. 10). Aquifer porosity of 20 percent was assumed based on the unconsolidated and variably sorted nature of the sand-and-gravel deposits composing the shallow aquifer (Freeze and Cherry, 1979). The distance and area covered by the particles in those time intervals define the ground-water recharge areas. The northern two-thirds of Silver Lake receives its recharge from the area between Silver Lake and Big Cedar Lake, however, the 50-year time-of-travel does not extend all the way to Big Cedar Lake (fig. 10). The southern one-third of Silver Lake receives its recharge from the area between Silver Lake and Little Cedar Lake. The 10-year time-oftravel for this part of Silver Lake does not extend all the way to Little Cedar Lake, but the 20-year time of travel does reach the eastern shore of Little Cedar Lake. Therefore, for times of travel greater than 15 or 20 years, the recharge area of Little Cedar Lake also should be considered a recharge area for Silver Lake. Because Little Cedar Lake receives surface-water flow from Big Cedar Lake, it also should be considered a potential recharge area for the southern portion of Silver Lake for times-of-travel greater than 15 or 20 years. Forward particle tracking confirmed the areas of contribution delineated by the backward tracking. Once ground water enters Silver Lake, whether it comes from the northern two-thirds or southern one-third of the western shoreline, the water likely becomes wellmixed.

The porosity value given the shallow aquifer is a controlling factor in the simulated time-of-travel for the mathematical water particles tracked backward from Silver Lake to define the ground-water recharge areas. Porosity greater than 20 percent would decrease the distance traveled by particles over a given time, and porosity less than 20 percent would increase the distance traveled. However, over the range of reasonable porosity values ( 15 to 25 percent), the difference in distance traveled is small (plus or minus 20 percent of the distance traveled at 20 percent porosity).

\section{Simulation of Pumping from the Shallow Aquifer}

The effect of a pumping well on the shallow aquifer and Silver Lake can be evaluated anywhere in the model near-field. As examples, wells were added to the calibrated model at three locations, one west of Silver Lake (upgradient), one directly east of Silver Lake (downgradient), and one further to the southeast of Silver Lake (fig. 11a). The latter location is near a newly built shopping center in an area where future development is likely. Each simulated well is represented as fully penetrating and pumps at a rate of $0.17 \mathrm{ft}^{3} / \mathrm{s}$ ( 75 gallons per minute-about average for municipal wells in the nearby city of West Bend). The effect of each well is simulated independently of the others.

Simulated pumping at each location is shown to lower the water table locally (figs. $11 \mathrm{~b}, \mathrm{c}$, and d). Backward particle tracking was used to define the upgradient area contributing recharge to each well. The contributing areas extend to the west; Silver Lake is included in the contributing areas for the two downgradient wells. Because simulated flows from the shallow aquifer to Silver Lake and from Silver Lake to the shallow aquifer are small, 1.08 and $0.08 \mathrm{ft}^{3} / \mathrm{s}$ respectively (fig. 9), the model simulates that the wells affect the lake water balance. The effect can be seen in slightly lowered lake stage and reduced outflow to Silver Creek. The simu- 


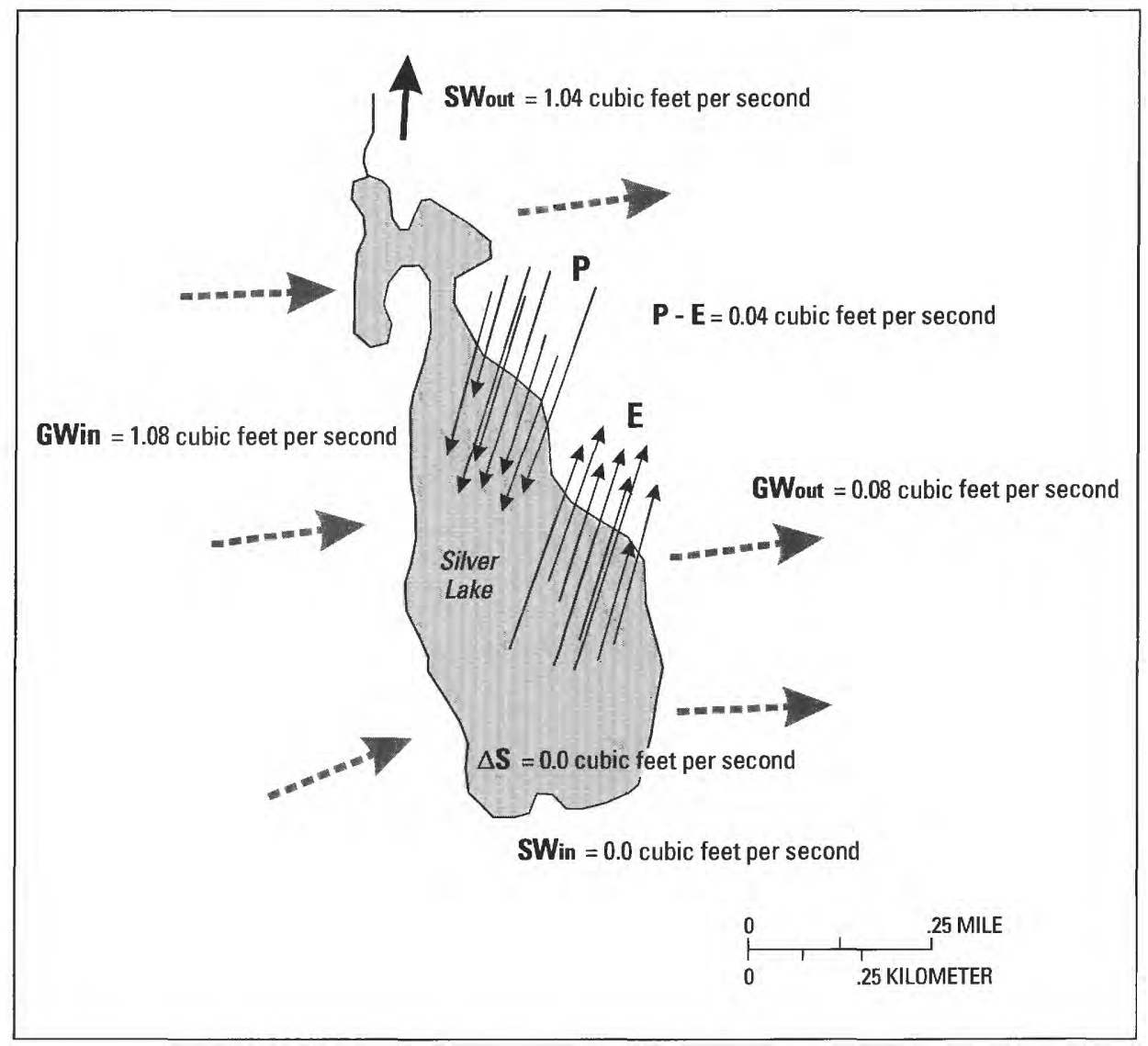

\section{EXPLANATION}

$\downarrow$ Precipitation

Evaporation

7 Direction of ground-water flow
Direction of surface-water flow

Equation definitions

GWin Ground-water flow into Silver Lake

GWout Ground-water flow out of Silver Lake

SWin Surface-water flow into Silver Lake

SWout Surface-water flow out of Silver Lake into Silver Creek

P Precipitation falling on the surface of Silver Lake

E Evaporation from the surface of Silver Lake

Figure 9. Hydrologic budget for Silver Lake, Washington County, Wisconsin, based on the calibrated analytic-element model. 


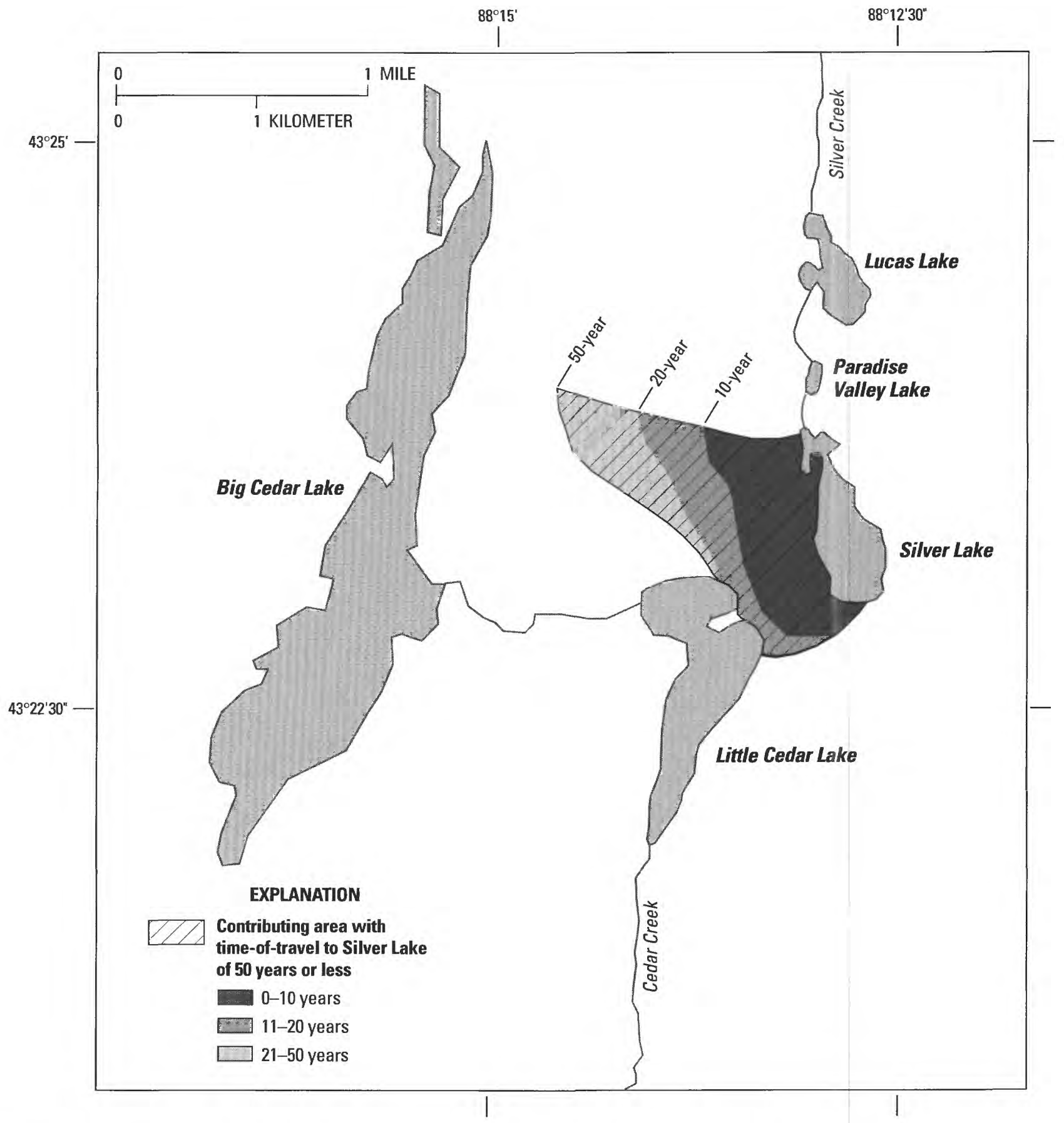

Figure 10. Ground-water recharge areas and times-of-travel to Silver Lake, Washington County, Wisconsin. 


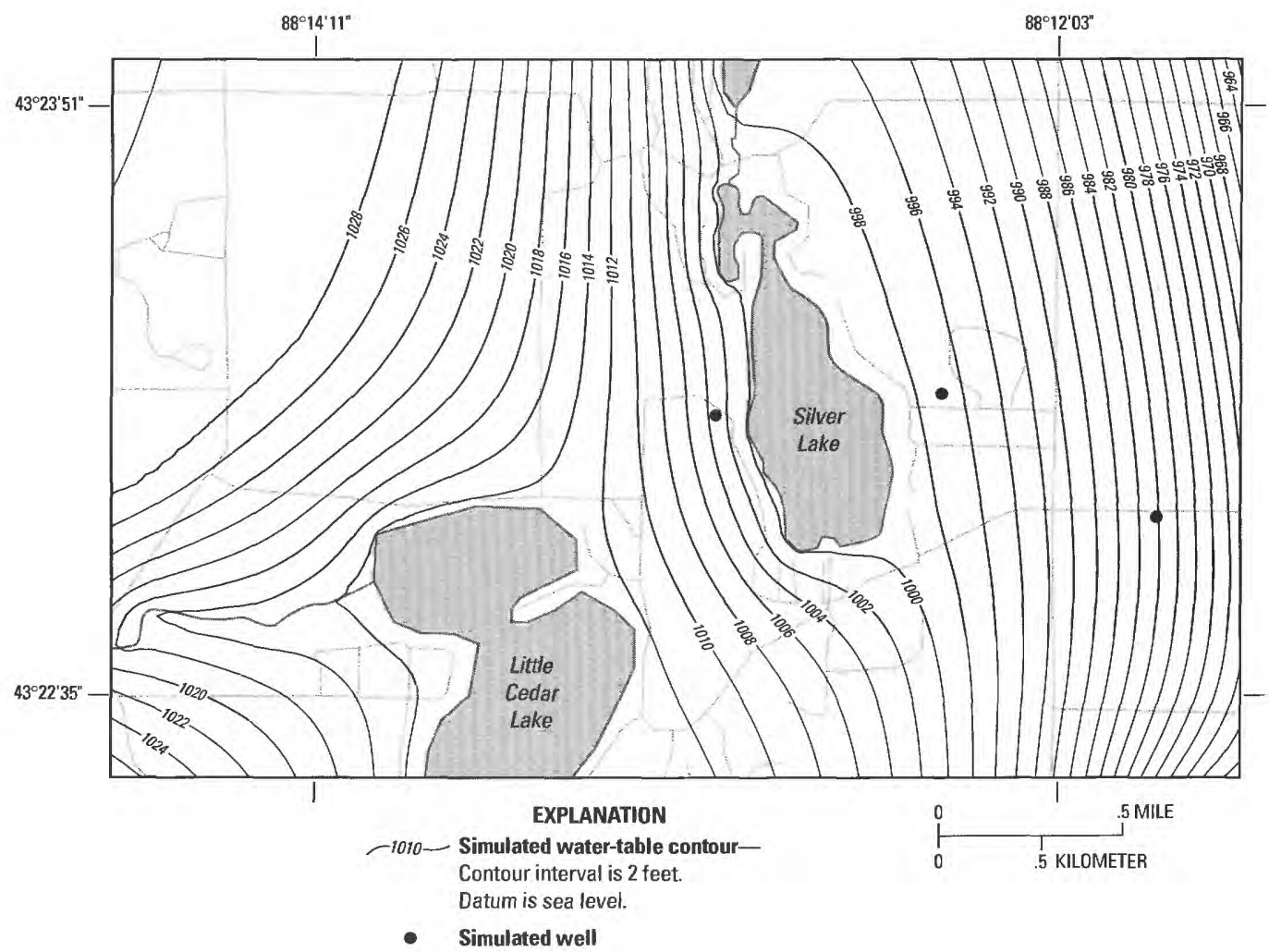

Figure 11a. Locations of three simulated wells around Silver Lake, Washington County, Wisconsin.

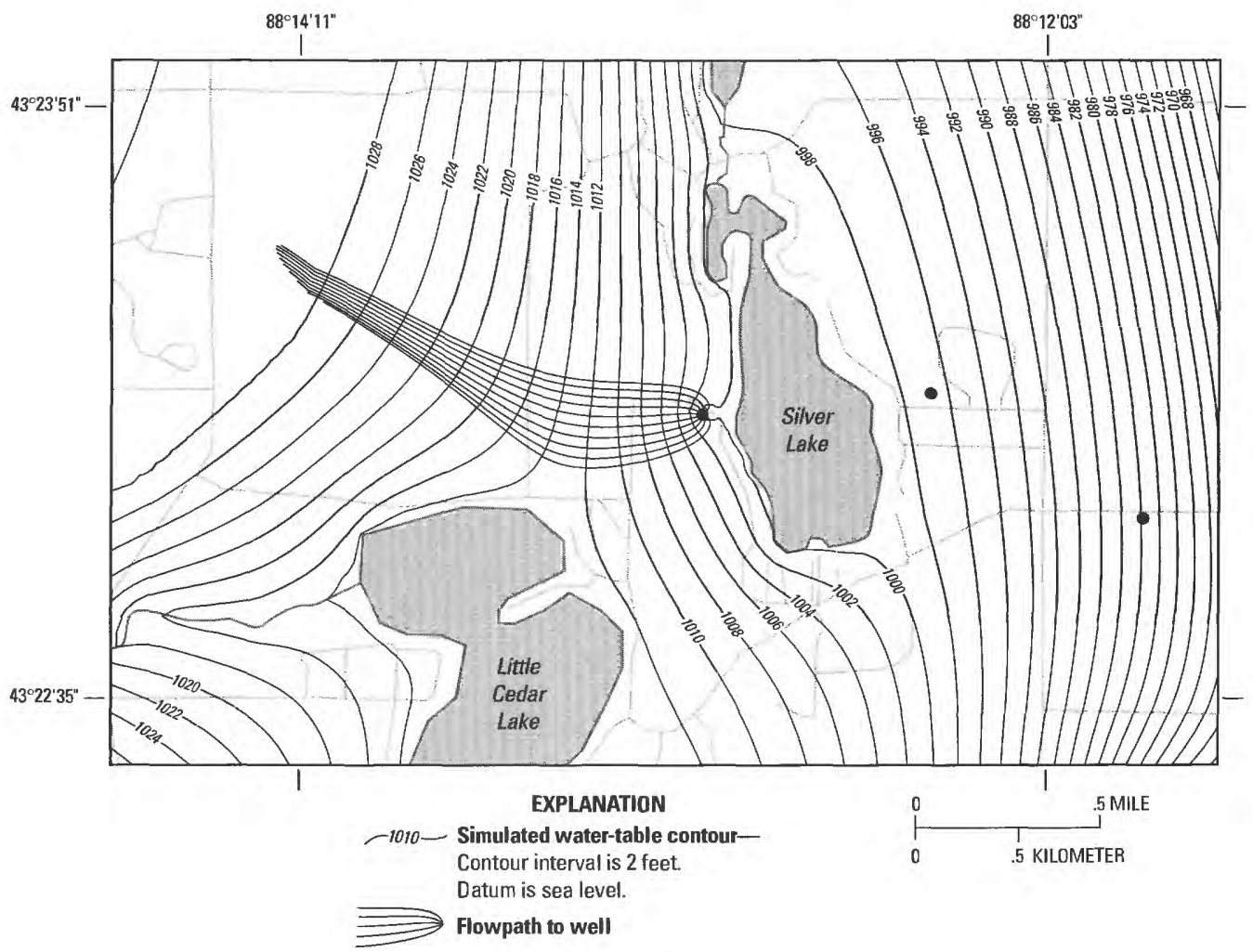

Figure 11b. Simulated fully-penetrating well pumping 75 gallons per minute from west side of Silver Lake, Washington County, Wisconsin. 


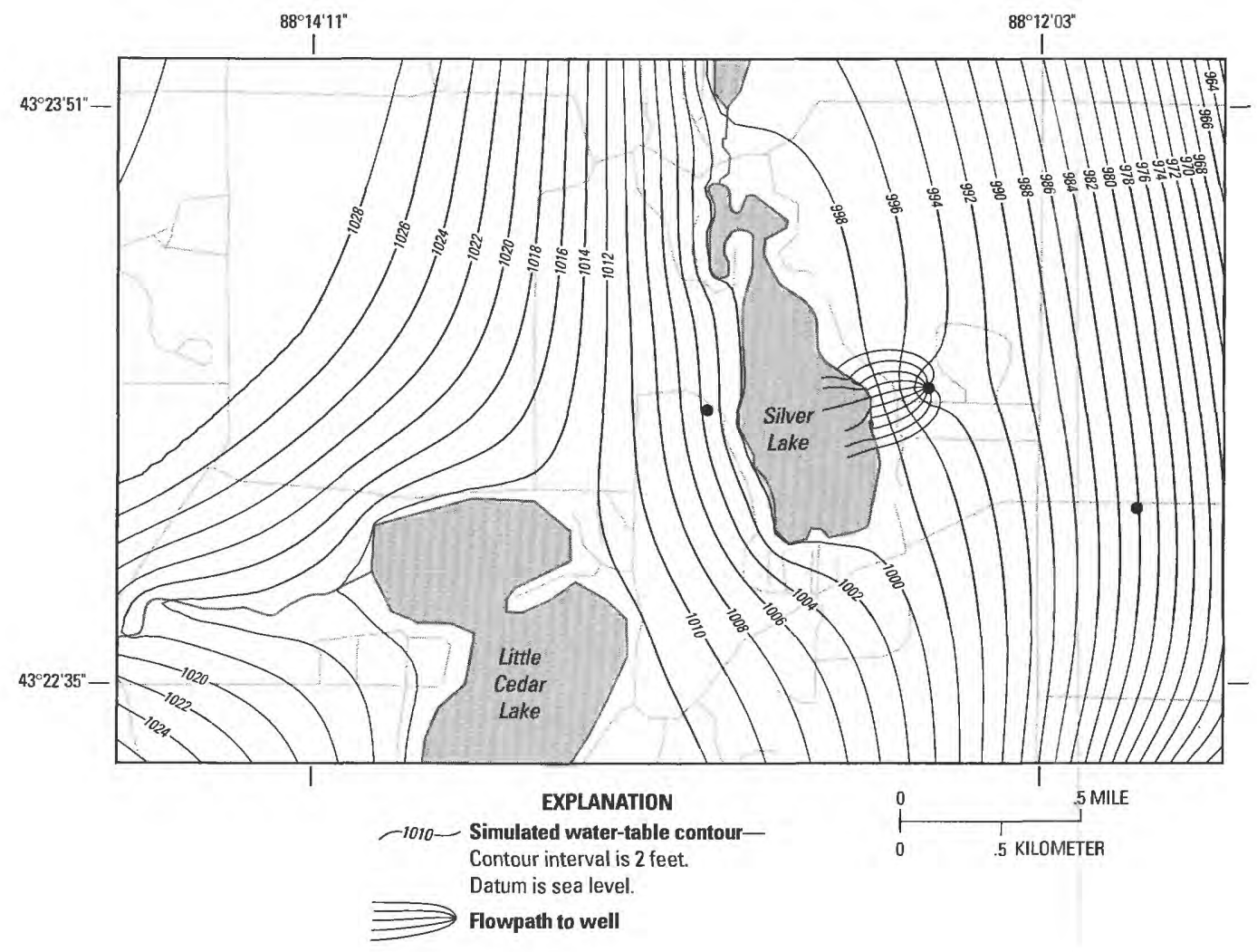

Figure 11c. Simulated fully-penetrating well pumping 75 gallons per minute from east of Silver Lake, Washington County, Wisconsin.

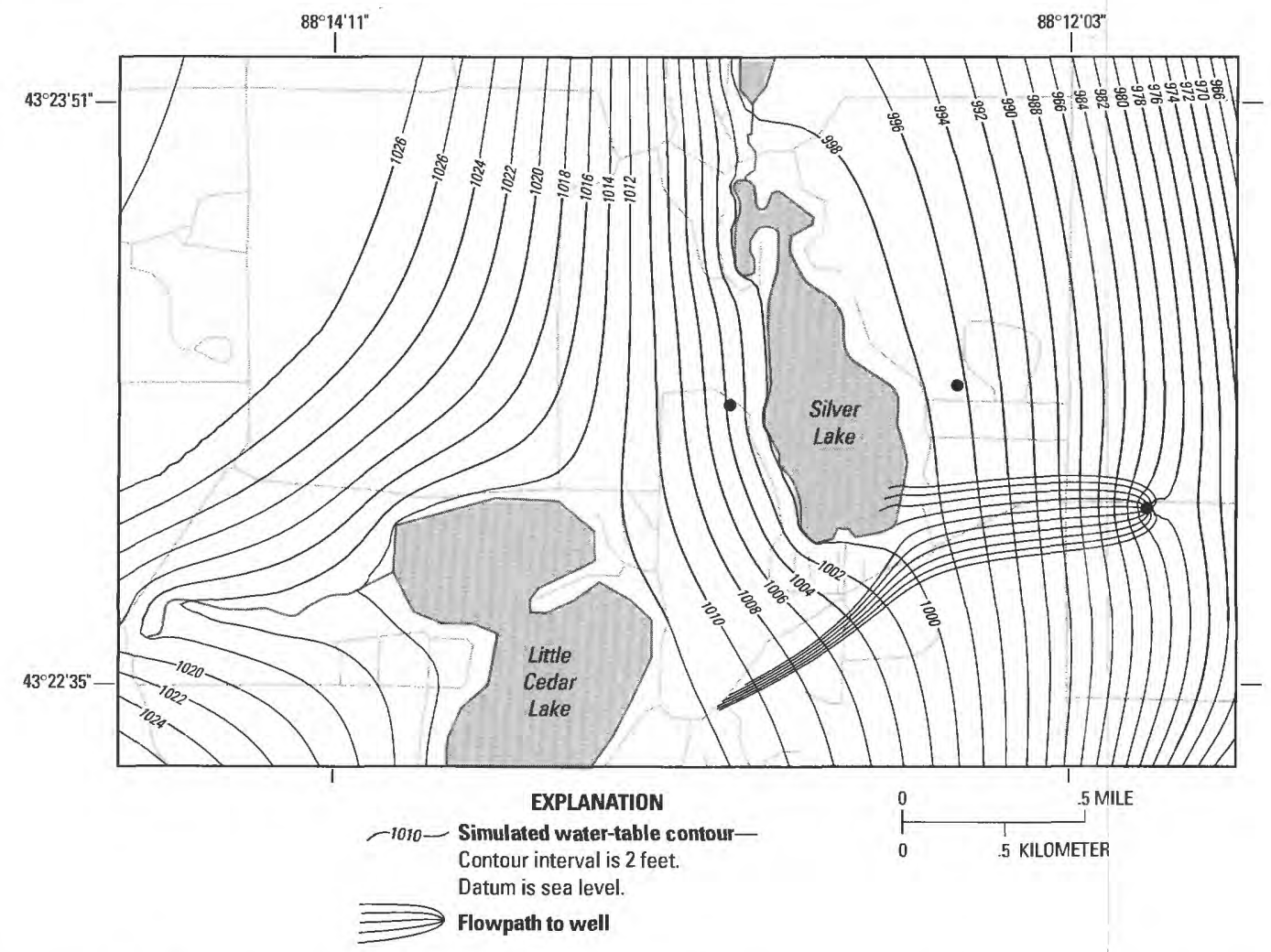

Figure 11d. Simulated fully-penetrating well pumping 75 gallons per minute from southeast side of Silver Lake, Washington County, Wisconsin. 
Table 5. Average solute concentrations in ground water and resulting mass flux toward Silver Lake, Washington County, Wisconsin

[mg/L, milligrams per liter; $\mathrm{ft}^{3} / \mathrm{s}$, cubic feet per second; L/d. liters per day; $\mathrm{Kg} / \mathrm{d}$, kilograms per day]

\begin{tabular}{|c|c|c|c|c|}
\hline Constituent & $\begin{array}{c}\text { Average concentration in } \\
\text { upgradient observation } \\
\text { wells } \\
(\mathrm{mg} / \mathrm{L})\end{array}$ & $\begin{array}{l}\text { Daily ground water flux } \\
\text { toward Silver Lake } \\
\left(\mathrm{ft}^{3} / \mathrm{s}\right)\end{array}$ & $\begin{array}{l}\text { Daily ground water } \\
\text { flux toward Silver Lake } \\
\text { (L/d) }\end{array}$ & $\begin{array}{l}\text { Daily solute mass flux } \\
\text { toward Silver Lake } \\
\text { (Kg/d) }\end{array}$ \\
\hline Total Nitrogen & 3.65 & 1.08 & $2,642,302$ & 9.64 \\
\hline Chloride & 12.4 & 1.08 & $2,642,302$ & 32.76 \\
\hline Phosphorous & .023 & 1.08 & $2,642,302$ & .06 \\
\hline
\end{tabular}

lated stage of Silver Lake is lowered very little0.005 to $0.013 \mathrm{ft}$-by the pumping wells (figs. $11 \mathrm{~b}, \mathrm{c}$, and d). Based on the historical relation between Silver Lake stage (as controlled by the dam) and Silver Creek outflow (table 4), GFLOW provides Silver Creek outflow for these same simulations of pumping wells. The simulated outflow from Silver Lake to Silver Creek is reduced by 0.05 to $0.14 \mathrm{ft}^{3} / \mathrm{s}$ (figs. $11 \mathrm{~b}, \mathrm{c}$, and d).

\section{Solute Flux Toward Silver Lake}

Ground water flowing toward Silver Lake carries with it dissolved chemical constituents (solutes). However, ground water sampled from piezometers or monitoring wells on shore can have markedly different chemistries from water discharging across the sediment-water interface. This difference is true particularly for nutrients, such as nitrogen and phosphorus, and redox sensitive species (Krabbenhoft and Webster, 1995), largely because some biotic and abiotic chemical processes are concentrated near the sediment-water interface. Because of the chemical dynamics present at the sediment-water interface, it is important to sample pore water in the littoral regions of lakes in order to estimate chemical constituent loading from ground-water discharge (Krabbenhoft and Webster, 1995). Specifically, this sampling should be done within about $3 \mathrm{ft}$ of the sediment-water interface. A reasonable estimate of the flux of chemical constituents through the interface into Silver Lake cannot be done with analytical data from the available piezometers and observation wells; this would require a more thorough understanding of the character of the interface, its chemistry, and its effect on non-conservative constituents.
Concentrations measured in piezometers and observation wells during the course of the CDM/Limnetics study (CDM/Limnetics, 1977), however, can be used to estimate the flux of chemical constituents toward the interface. With the use of the 1976/1977 data for wells upgradient of Silver Lake, average concentrations for ground water approaching the aquifer/lake interface have been calculated for total nitrogen, chloride, and phosphorus (table 5). The mass flux of these solutes to this interface can be calculated by using the ground-water flux $\left(\mathrm{GW}_{\text {in }}\right)$ provided by the AE model$1.08 \mathrm{ft}^{3} / \mathrm{s}$. Table 5 shows the daily solute mass flux for constituents calculated by multiplying average concentrations by the ground-water flux. This provides an upper estimate of potential flux to the lake because reactions that typically occur at the sediment-water interface tend to reduce constituent concentrations.

\section{Model Limitations}

As with any ground-water model, the Silver Lake $\mathrm{AE}$ model is a simplification of actual ground-water flow, with proportional limitations on model precision and application. For instance, the contrast in transmissivity represented by the inhomogeneity is based on regional geology and model calibration. Whereas changes in transmissivity largely are related to variations in saturated thickness and hydraulic conductivity, the scale at which these factors can vary is much smaller than the scale of the inhomogeneity. Therefore, although general conclusions can be reached about ground-water flow across the inhomogeneity and in the vicinity of Silver Lake, evaluation of site-specific questions may require additional information or refinement 
of the model. In addition, the AE model employs the Dupuit-Fochheimer approximation that assumes ground-water flow is horizontal, so the model will not accurately represent the water table in areas where strong vertical gradients and/or flow are present. This limitation is not perceived to be a problem in the vicinity of Silver Lake. As a steady-state representation, seasonal fluctuations in Silver Lake and the shallow aquifer are not simulated.

\section{SUMMARY}

Silver Lake, in central Washington County, southeastern Wisconsin, could be affected adversely by hydrologic stresses to the shallow aquifer. In order to assess the potential effects of these stresses the U.S. Geological Survey, in cooperation with the Silver Lake Protection and Rehabilitation District, began a study in 2000.

Silver Lake is a kettle lake located in the Kettle Moraine Area. Silver Lake is about 117.6 ac in area, and is fed by small springs discharging near the shoreline and ground-water seepage. No streams flow into Silver Lake. Water flows from the north end of Silver Lake over a small dam into Silver Creek. Hydraulic parameter values for the shallow aquifer were estimated through characterization of the study area and calibration of the AE model. Based on results of the calibrated model, hydraulic conductivity of the shallow aquifer ranges from 20 to $50 \mathrm{ft} / \mathrm{d}$-lower in the Kettle Moraine Area and higher in the surrounding areas. Also based on the calibrated model, recharge rates vary from 4 to $12 \mathrm{in} / \mathrm{yr}$ - higher in the Kettle Moraine Area and lower in surrounding areas.

The hydrologic budget components for Silver Lake have been determined and their values estimated.

Streamflow from Silver Lake was computed as a residual in the hydrologic budget and compared to measured flows. Precipitation on the lake minus evaporation from the lake is reported in the literature to be about $0.04 \mathrm{ft}^{3} / \mathrm{s}$ ( $3 \mathrm{in} / \mathrm{yr}$ ). Model results show ground-water flow into Silver Lake is $1.08 \mathrm{ft}^{3} / \mathrm{s}$, and flow from Silver Lake to the shallow aquifer is $0.08 \mathrm{ft}^{3} / \mathrm{s}$. The residual of $1.04 \mathrm{ft}^{3} / \mathrm{s}$ is the streamflow from Silver Lake to Silver Creek and closely matches the low end of the range of measured flows.

Ground-water-recharge areas for Silver Lake have been simulated by using backward tracking of particles in the AE model. Assuming a porosity of 20 percent, areas were defined for travel times of 10, 20, and 50 years. Model simulations show that nearly all the ground water flowing to Silver Lake comes from recharge areas to the west. The recharge area for the northern two-thirds of Silver Lake lies west toward Big Cedar Lake, though the 50-year time-of-travel does not extend all the way to Big Cedar Lake. The recharge area for the southern one-third of Silver Lake lies west toward Little Cedar Lake. The simulated time of travel from Little Cedar Lake to Silver Lake is between 15 and 20 years.

Three wells pumped independently from the shallow aquifer at locations west, east, and southeast of Silver Lake were simulated. The simulated pump rate $(75$ gpm $\left.\left[0.17 \mathrm{ft}^{3} / \mathrm{s}\right]\right)$ is about twice the modeled flow from Silver Lake to the shallow aquifer $\left(0.08 \mathrm{ft}^{3} / \mathrm{s}\right)$ and about one-sixth the simulated flow from the shallow aquifer to Silver Lake $\left(1.08 \mathrm{ft}^{3} / \mathrm{s}\right)$. The simulated wells have an effect on the water balance of the lake. Depending on the placement of the well, the simulated stage of Silver Lake is lowered 0.005 to $0.013 \mathrm{ft}$, and the simulated outflow from Silver Lake to Silver Creek is reduced by 0.05 to $0.14 \mathrm{ft}^{3} / \mathrm{s}$.

The solute flux toward Silver Lake was estimated by using average concentrations measured in observation wells and the simulated ground-water flux. However, in order to estimate solute mass loading to Silver Lake from ground-water discharge, it would be necessary to characterize the nature of the sediment-water interface, as well as the chemistry of the pore water in the lake littoral region (within about $3 \mathrm{ft}$ of the interface). Concentrations of solutes like nitrogen and phosphorus would likely be lowered by biotic and abiotic processes near the sediment-water interface.

\section{REFERENCES}

Anderson, M.P., and Woessner, W.W., 1992, Applied Groundwater Modeling: San Diego, Calif., Academic Press, $381 \mathrm{p}$.

Bates, R.L., and Jackson, J.A., 1980, Glossary of Geology, Second Edition: Falls Church, Virginia, American Geological Institute, $749 \mathrm{p}$.

CDM/Limnetics, 1977, An environmental study of Silver Lake and the hydrological and water quality characteristics of its associated watershed for the Inland Lake Protection and Rehabilitation District of Silver Lake, Washington County, Wisconsin: Report submitted to Silver Lake Protection and Rehabilitation District. 
Freeze, R. A., and Cherry, J. A., 1979, Groundwater: New Jersey, Prentice-Hall, Inc., 604 p.

Haitjema, H.M., 1995, Analytic Element Modeling of Groundwater Flow: San Diego, Calif., Academic Press, $394 \mathrm{p}$.

Hunt, R.J., Anderson, M.P., and Kelson, V.A., 1998, Improving a complex finite-difference ground water flow model through the use of an analytic element screening model: Ground Water, v. 36, no. 6, p. 1011-1017.

Hunt, R.J., Haitjema, H.M., Krohelski, J.T., and Feinstein, D.T., in press, Simulating lake-ground water interactions with models: MODFLOW and analytic element approaches: Ground Water.

Hunt, R.J., and Krohelski, J.T., 1996, The application of an analytic element model to investigate groundwater-lake interactions at Pretty Lake, Wisconsin: Journal of Lake and Reservoir Management, v. 12, no. 4, p. 487-495.

Krabbenhoft, D.P., and Webster, K.E., 1995, Transient hydrogeological controls on the chemistry of a seepage lake: Water Resources Research, vol. 31, no. 9, p. 2295-2305.

Lillie, R.A., and Mason, J. W., 1983, Limnological Characteristics of Wisconsin Lakes: Wisconsin Department of Natural Resources Technical Bulletin No. 138, 116 p.

Mickelson, D.M., and Syverson, K.M., 1997, Quaternary geology of Ozaukee and Washington Counties, Wisconsin: Wisconsin Geological and Natural History Survey Bulletin 91, 56 p.

Neild, S.P., Townley, L.R., and Barr, A.D., 1994, A framework for quantitative analysis of surface water-groundwater interaction - Flow geometry in vertical section: Water Resources Research, 30(8), p. 2461-2475.
Novitzki, R.P., 1982, Hydrology of Wisconsin Wetlands: Wisconsin Geological and Natural History Survey Information Circular Number 40, 22 p.

Poeter, E.P., and Hill, M.C., 1998, Documentation of UCODE, A computer code for universal inverse modeling: U.S. Geological Survey Water-Resources Investigations Report 98-4080, 116 p.

Poff, R.J., and Threinen, C. W., 1962, Surface Water Resources of Washington County: Lake and Stream Classification Project, Wisconsin Conservation Department, $65 \mathrm{p}$.

Rantz, S. E., and others, 1982, Measurement and Computation of Streamflow: U.S. Geological Survey Water-Supply Paper 2175, $631 \mathrm{p}$.

Shaw, B., Mechenich, C., and Klessig, L., 1986, Understanding Lake Data: G3582, UW-Extension Cooperative.

Strack, O.D.L., 1989, Groundwater Mechanics: Englewood Cliffs, N.J., Prentice-Hall, 732 p.

U.S. Geological Survey, 1997, Water quality and lake-stage data for Wisconsin lakes, water year 1996: U.S. Geological Survey Open-File Report 97-123, 134 p.

U.S. Geological Survey, 1998, Water quality and lake-stage data for Wisconsin lakes, water year 1997: U.S. Geological Survey Open-File Report 98-78, 129 p.

Water Quality Association, September 24, 1999, Glossary of Terms: accessed January 16, 2002, at URL http://www.wqa.org/glossary.cfm?gl=2002. 
APPENDIX 


\section{APPENDIX}

U.S. Geological Survey water-chemistry analyses and physical measurements for Silver Lake, Washington County, Wisconsin (U.S. Geological Survey, 1997; U.S. Geological Survey, 1998). 


\section{SILVER LAKE NEAR WEST BEND, WI}

LOCATION.--Lat $43^{\circ} 23^{\prime} 22^{\prime \prime}$, long $88^{\circ} 12^{\prime} 50^{\prime \prime}$, in NE 1/4 SW 1/4 sec.27, T.11 N., R.19 E., Washington County, Hydrologic Unit 04040003, 1.4 mi southwest of West Bend.

PERIOD OF RECORD.--February 1996 to August 1997 (discontinued).

REMARKS.--Lake sampled at northern end of southern basin of lake at the deep hole. Lake ice-covered during February measurements.

Water-quality analyses by Wisconsin State Laboratory of Hygiene.

WATER-QUALITY DATA, FEBRUARY 13 TO AUGUST 26, 1997

(Milligrams per liter unless otherwise indicated)

Feb. 13 Apr. 22

Lake stage (ft)

Secchi-depth (meters)

Chlorophyll a, phytoplankton $(\mu \mathrm{g} / \mathrm{L}$

Depth of sample (m)

water temperature $\left({ }^{\circ} \mathrm{C}\right)$

Specific conductance $(\mu \mathrm{s} / \mathrm{cm})$

pH (units)

Dissolved oxygen

Phosphorus, total (as P)

Phosphorus, orthoi dissolved (as P)

-.-

11.08

5.4

$--$

0.513

$2.5 \quad 4.0$

511

1582

8.27 .6

11.40 .9

$<0.007 \quad 0.060$

$\begin{array}{rrrr}-. & 0.060 & 0.017<0.008 \\ \ldots & 0.002 & 0.002\end{array}$

- -

NO2 + NO3, diss. (as

Nitrogen, ammonia, dissolved (as $N$ )

Nitrogen, amm. + org., total (as N)

Nitrogen, total (as N)

Color (Pt-Co. scale)

Turbidity (NTU)

Hardness, as $\mathrm{CaCO}_{3}$

Calcium, dissolved (Ca)

Magnesium, dissolved (Mg)

sodium, dissolved ( $\mathrm{Na}$ )

Potassium, dissolved (K)

Alkalinity, as $\mathrm{CaCO} 3$

Sulfate, dissolved (SO4)

Chloride, dissolved ( $\mathrm{Cl}$ )

Silica, dissolved (SiO2)

Solids, dissolved, at $180^{\circ} \mathrm{C}$

Iron, dissolved ( $\mathrm{Fe}) \mu \mathrm{g} / \mathrm{L}$

Manganese, dissolved (Mn) $\mu \mathrm{g} / \mathrm{L}$ 2-13-97
-

-

- - $\quad--$

-

-. $\quad-. \quad 260$

-. $\quad \ldots \quad 46$

- - - - -

‥ $\quad \ldots$

-

-

- - $\quad--$

19

$\ldots \quad-\ldots \quad 298$

$-\cdots$

4-22-97
-

-

$---10<10<10$
June 11

\begin{tabular}{|c|c|}
\hline \multicolumn{2}{|c|}{ June 11} \\
\hline \multicolumn{2}{|c|}{11.09} \\
\hline \multicolumn{2}{|c|}{2.7} \\
\hline \multicolumn{2}{|c|}{1.7} \\
\hline 0.5 & 13 \\
\hline 22.0 & 7.0 \\
\hline 508 & 537 \\
\hline 8.2 & 7.5 \\
\hline 10.6 & 0.1 \\
\hline 0.024 & 0.102 \\
\hline--- & -- \\
\hline--- & -- \\
\hline-- & $\ldots$ \\
\hline-- & $\ldots$ \\
\hline-- & -- \\
\hline--- & --- \\
\hline-- & -- \\
\hline$\ldots$ & --- \\
\hline$-\cdots$ & --- \\
\hline-- & -- \\
\hline--- & --- \\
\hline-- & --- \\
\hline.- & -- \\
\hline-- & $\ldots$ \\
\hline.- & $\ldots$ \\
\hline-- & -- \\
\hline-- & -- \\
\hline-- & --- \\
\hline-- & -- \\
\hline
\end{tabular}

7-24-97

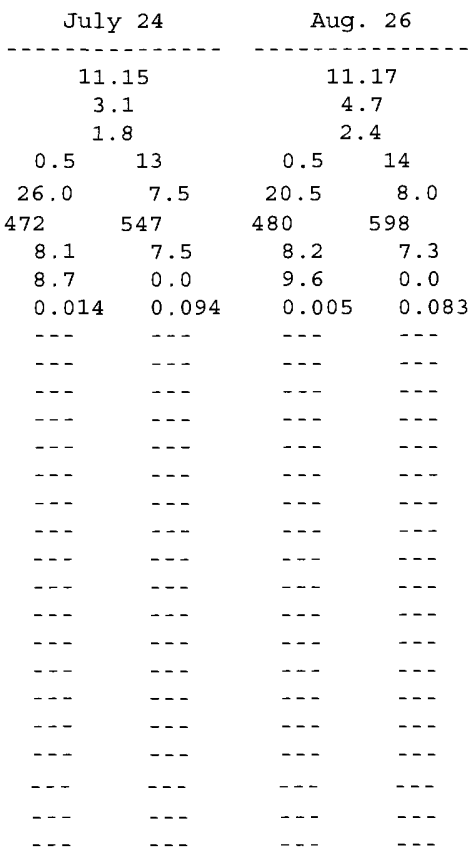

8-26-97

DISSOLVED OXYGEN (D.O.), IN MILLIGRAMS PER LITER
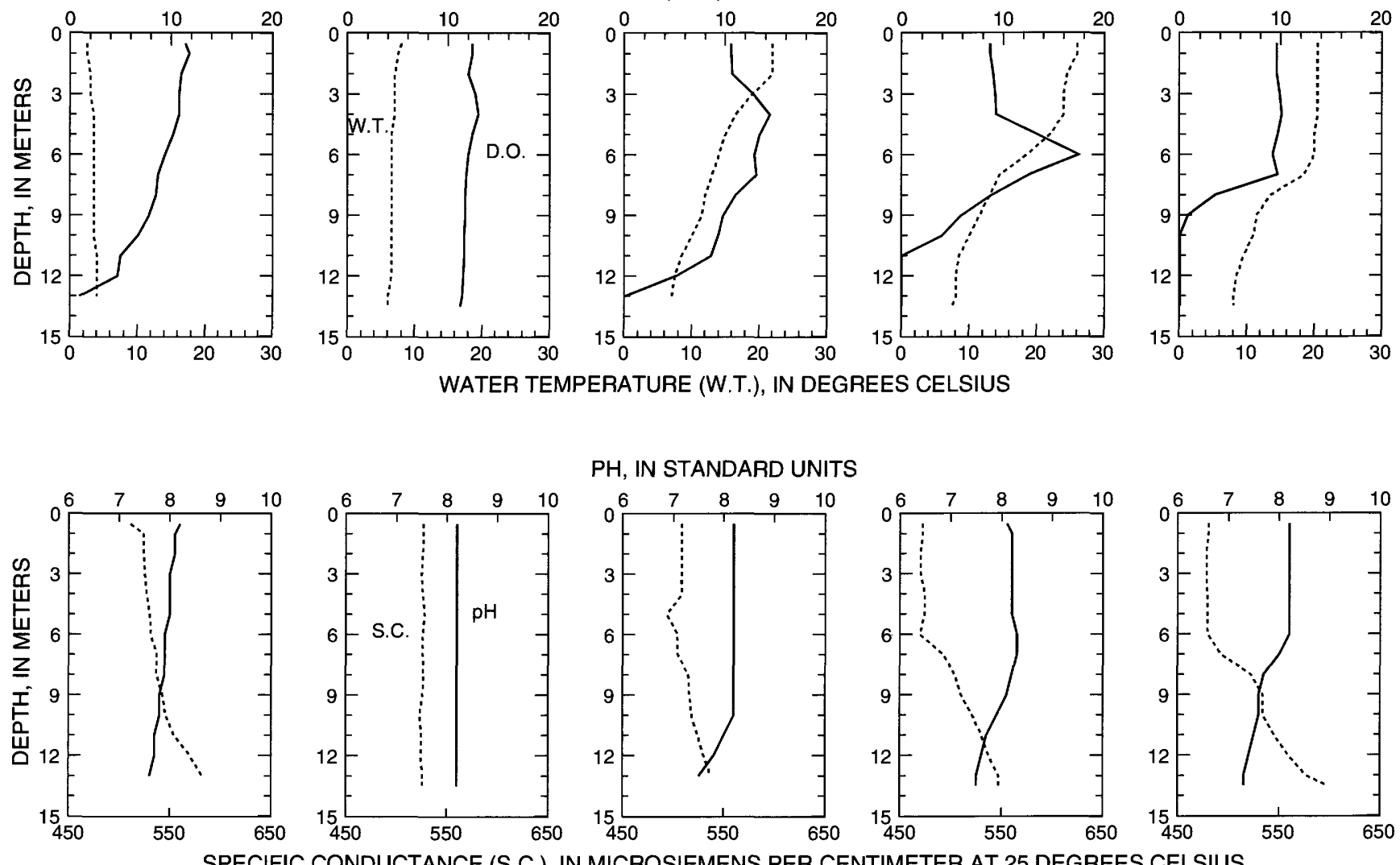

$\mathrm{PH}$, IN STANDARD UNITS
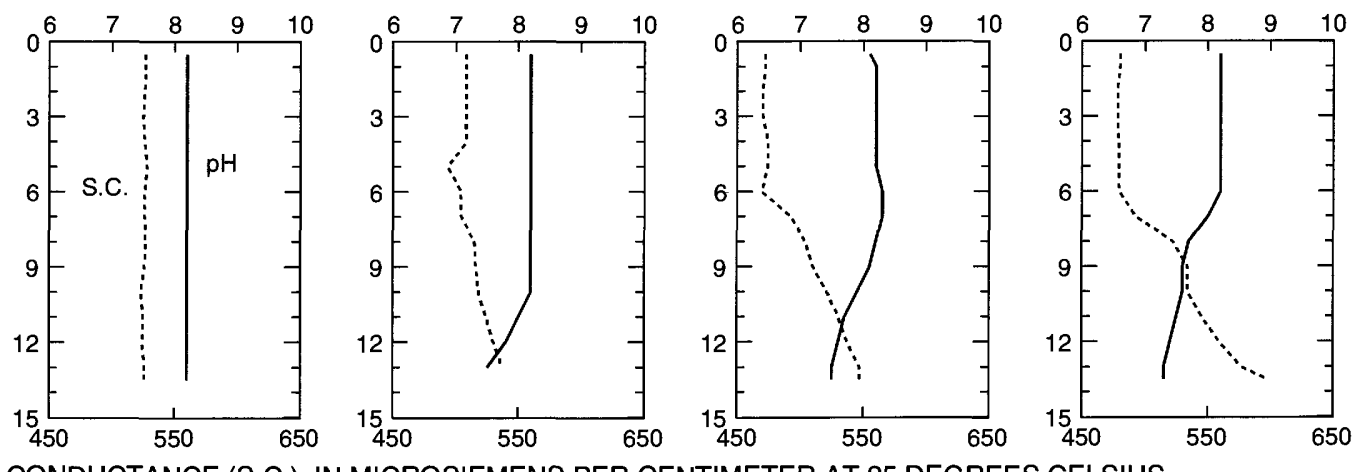

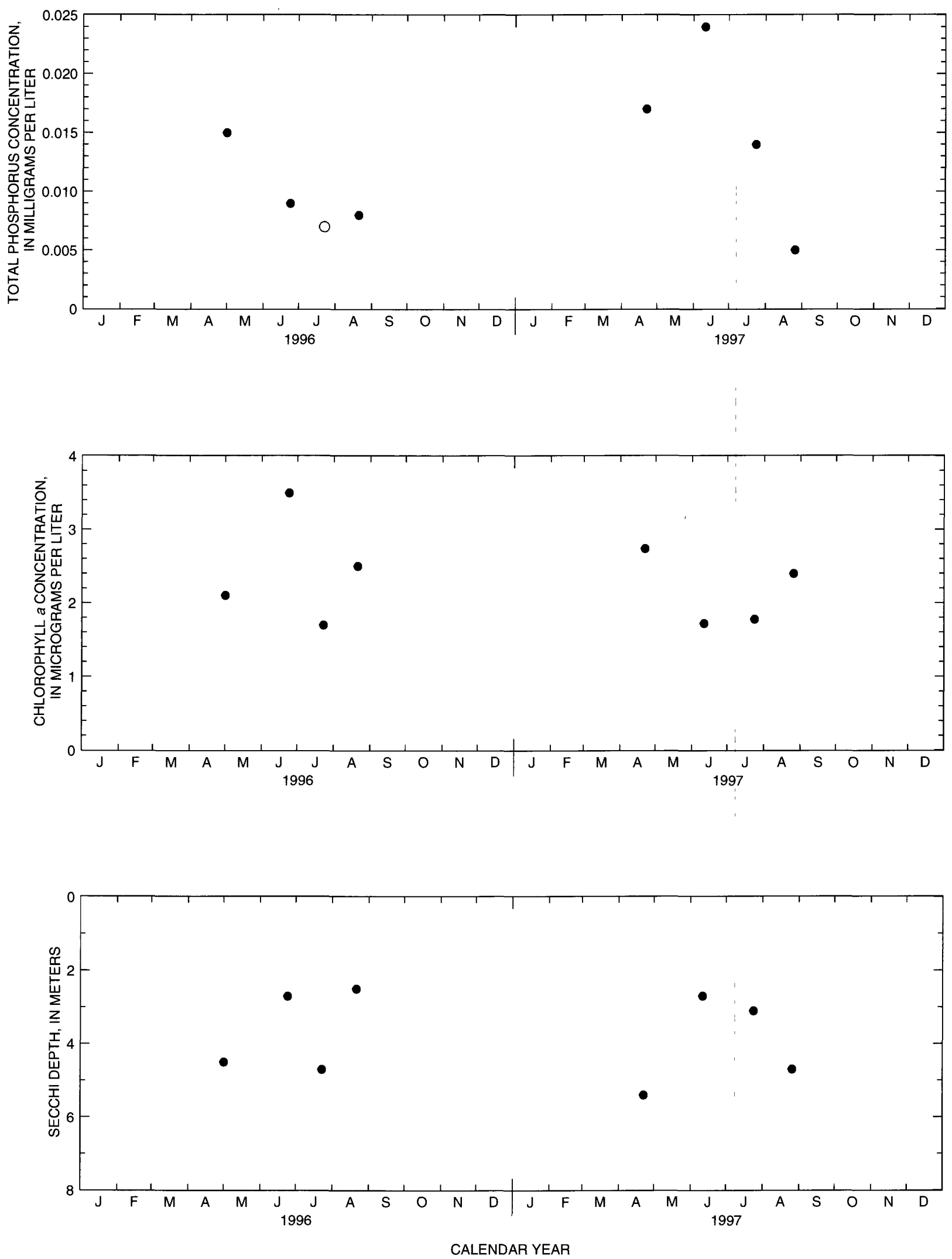

Surface total phosphorus and chlorophyll a concentrations, and Secchi depths for Silver Lake near West Bend, Wisconsin. 


\section{SILVER LAKE NEAR WEST BEND, WI}

LOCATION.--Lat 43"23'22", long 88'12'50", in NE 1/4 SW 1/4 sec.27. T.II N., R.19 E., Washington County, Hydrologic Unit 04040003 , $1.4 \mathrm{mi}$ southwest of West Bend.

PERIOD OF RECORD.--February to August 1996.

REMARKS.--Lake sampled at northern end of southern lobe of lake at the deep hole. Lake ice-covered during February measurements. Water-quality analyses by Wisconsin State Laboratory of Hygiene.

Depth of sample $(\mathrm{ft})$
Lake stage $(\mathrm{ft})$ Specific conductance $\{\mu \mathrm{s} / \mathrm{cm}$ ! of lunits!

Water temperature ("c)

Color (Pt-co. scale)

Turbidity (Nrv)

Secchi-depch (meters)

Dissolved oxygen

Hardness, as $\mathrm{CaCO}_{3}$

Calciun, dissolved ( $\mathrm{Ca}$

Magnesium, dissolved (Mg)

Sodium, dissolved (Na)

Potassium, dissolved (K)

Mlkalinity, as CaCo3

Sulfate, dissolved (SO4)

Chloride, dissolved (Cl)

Fluoride, dissolved (F)

silica, dissolved (sioz)

solids, dissolved at $180^{\circ} \mathrm{C}$

Nitrogen, $\mathrm{NO}_{2}+\mathrm{NO}_{3}$, diss. (as N)

Nitrogen, ammonia, dissolved (as $\mathbf{N}$

Mitrogen, organic, total (as $N$ )

Nitrogen, ans. + org., total (as N)

Nitrogen, tot i is

thosphorus, total (as

Phoshorus, tartho las p)

Phosphor

Menese dissolved (Mn) $\mu g / L$

Chlorophyil a, phytoplankton $(\mu \mathrm{g} / \mathrm{L}) \ldots$

WATER-QUALITY DATA, FEBRUARY (4 TO AUGUST 21, 1996 (Milligrams per liter unless otherwise indicated)

\begin{tabular}{|c|c|c|c|c|c|c|c|c|c|}
\hline & 14 & May & 01 & sur & 24 & Jul & & Aug & \\
\hline 3.0 & 45 & 1.5 & $\ldots 4$ & 1.5 & 45 & 1.5 & & 2.5 & $9^{45}$ \\
\hline $\begin{array}{r}23 \\
8.2 \\
2.5\end{array}$ & $\begin{array}{r}583 \\
7.6 \\
4.0\end{array}$ & $\begin{array}{r}507 \\
8.2 \\
9.0\end{array}$ & $\begin{array}{r}508 \\
7.9 \\
7.0\end{array}$ & $\begin{array}{r}463 \\
8.5 \\
21.0\end{array}$ & $\begin{array}{r}546 \\
7.6 \\
8.5\end{array}$ & $\begin{array}{r}451 \\
8.4 \\
23.5\end{array}$ & $\begin{array}{l}66 \\
7.1 \\
8.5\end{array}$ & $\begin{array}{r}442 \\
8.2 \\
24.5\end{array}$ & $\begin{array}{l}79 \\
7.4 \\
9.0\end{array}$ \\
\hline$\therefore$ & $-\cdots$ & 5 & $5^{-2}$ & $=\infty$ & $\ldots$ & - & $\ldots$ & $\ldots$ & $\because .0$ \\
\hline$\cdots$ & $\cdots$ & 0.50 & $5^{0.60}$ & $\cdots$ & $7^{-\infty}$ & $\cdots$ & $\cdots$ & $\cdots-2$ & $-\cdots$ \\
\hline 11.6 & 1.0 & 20.8 & 8.4 & 10.1 & 0.3 & 9.5 & 0.2 & 9.0 & 0.2 \\
\hline$\cdots$ & 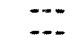 & $\begin{array}{r}250 \\
44\end{array}$ & $\begin{array}{r}260 \\
44\end{array}$ & $\ldots$ & $\cdots$ & -- & $m$ & $=-$ & $=$ \\
\hline$\cdots$ & $\cdots$ & 35 & 36 & $\ldots$ & $\cdots$ & $\ldots$ & $\cdots$ & -- & $\ldots$ \\
\hline$\cdots$ & -- & 8.5 & 8.5 & $\cdots$ & $\cdots$ & $\cdots$ & $\cdots$ & $\cdots$ & $\cdots$ \\
\hline$\cdots$ & -- & 1 & 1 & $\cdots$ & $\cdots$ & $-\cdots$ & $\cdots$ & $\cdots$ & $\cdots$ \\
\hline$\cdots$ & $\cdots$ & 240 & 240 & $\cdots$ & $\cdots$ & $\cdots$ & $\cdots$ & $-\infty$ & $\ldots$ \\
\hline$\cdots$ & $\cdots$ & 20 & 21 & $\cdots$ & $\cdots$ & $\cdots$ & $\cdots$ & $\cdots$ & $\cdots$ \\
\hline$\cdots$ & $\cdots$ & 19 & 19 & -.- & -.. & $\cdots$ & $\cdots$ & -- & $=-$ \\
\hline$\cdots$ & $\cdots$ & 0.1 & 0.1 & $\cdots$ & $\cdots$ & $\cdots$ & -. & $\cdots$ & $\cdots$ \\
\hline$\cdots$ & $\cdots$ & 12 & 13 & $\cdots$ & $\cdots$ & $\cdots$ & $\cdots$ & $\cdots$ & $-\cdots$ \\
\hline$\cdots$ & $\cdots$ & 296 & 294 & $\cdots$ & $\cdots$ & $\cdots$ & $\cdots$ & $\cdots$ & $\cdots$ \\
\hline$\cdots$ & $\ldots$ & 0.11 & 0.11 & $\cdots$ & $\cdots$ & -- & $\cdots$ & $\cdots$ & $-\cdots$ \\
\hline$\cdots$ & $\cdots$ & 0.32 & 0.43 & $\cdots$ & $\cdots$ & $\cdots$ & $\cdots$ & $\cdots$ & $\cdots$ \\
\hline$-\cdot$ & $\cdots$ & 0.48 & 0.47 & $\cdots$ & -- & $\cdots$ & $\cdots$ & $\cdots$ & $\cdots$ \\
\hline$\rightarrow$ & $\cdots$ & 0.80 & 0.90 & $\cdots$ & $-\infty$ & $\cdots$ & 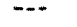 & $\cdots$ & $=-$ \\
\hline$-\infty$ & $m$ & 0.91 & 1.0 & $\cdots \bar{n}$ & 0.046 & $<\overline{0.007}$ & 0.072 & 0.008 & 0005 \\
\hline$\cdots$ & $\ldots$ & $\begin{array}{r}0.015 \\
<0.002\end{array}$ & $\begin{array}{r}0.015 \\
<0.002\end{array}$ & 0.009 & $\begin{array}{l}0.046 \\
\ldots\end{array}$ & 20.00 & 0.072 & 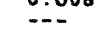 & 0.065 \\
\hline-- & $\therefore-$ & $<10$ & $<10$ & $\cdots$ & $\cdots$ & -- & $\cdots$ & $=-$ & $\cdots$ \\
\hline$\cdots$ & $\cdots$ & $<0.4$ & 2 & $=$ & $\cdots$ & $\cdots$ & $\cdots$ & $\cdots$ & $\cdots$ \\
\hline$\cdots$ & $\cdots$ & 2.1 & $\cdots$ & 3.5 & $\cdots$ & 1.7 & $\cdots$ & 2.5 & $=-$ \\
\hline
\end{tabular}

2-14-96

5.1 .96

$6-24-96$

$7-23-96$

$8-21-96$

DISSOLVED OXYGEN (D.O.), IN MILLIGRAMS PER LITER
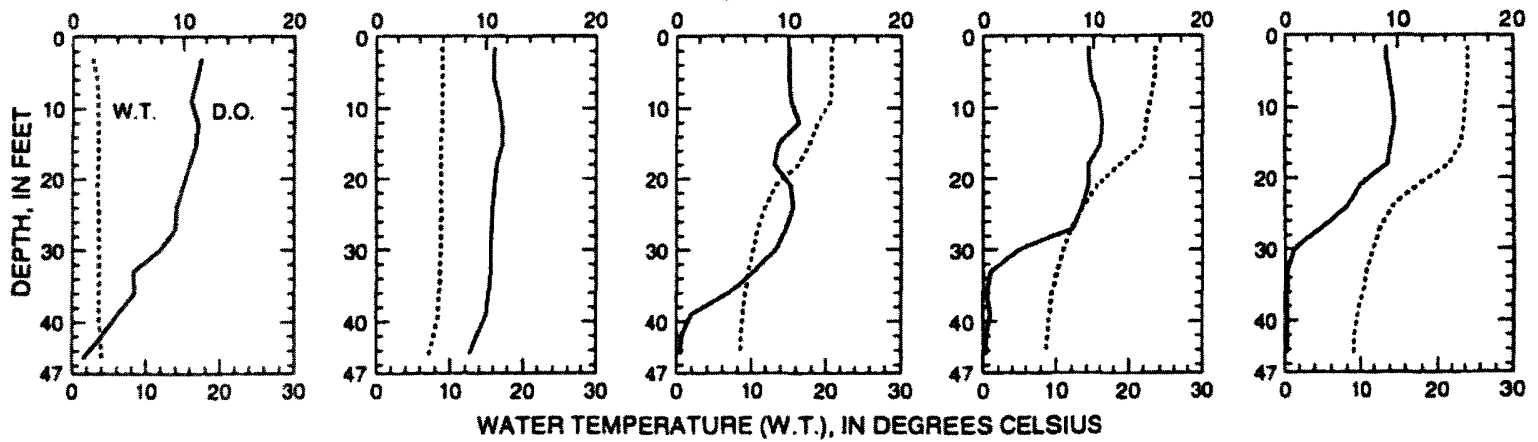

PH, IN STANDARD UNITS
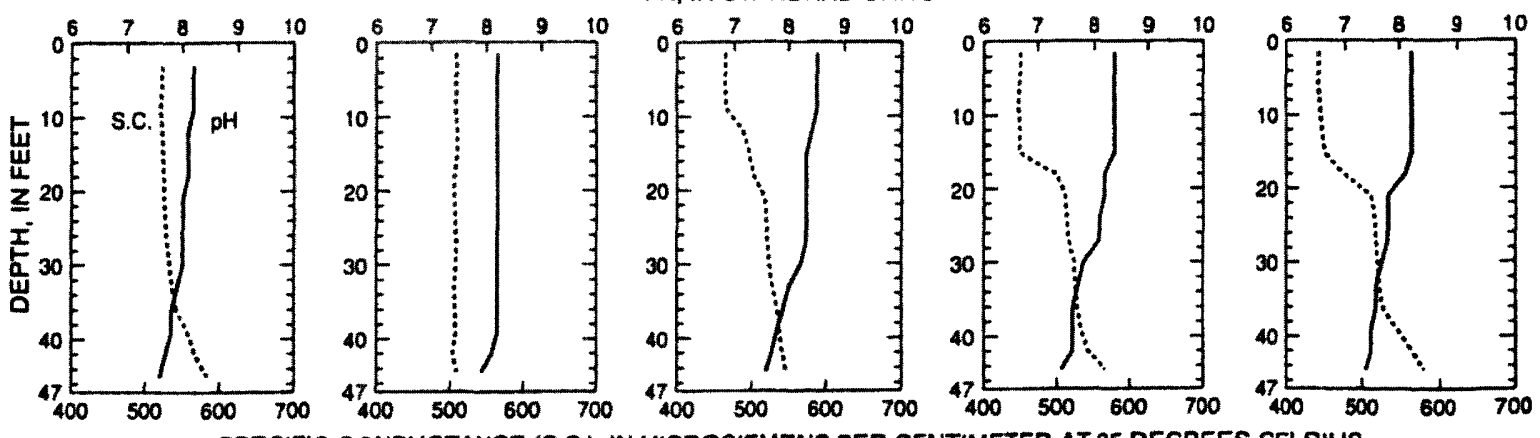


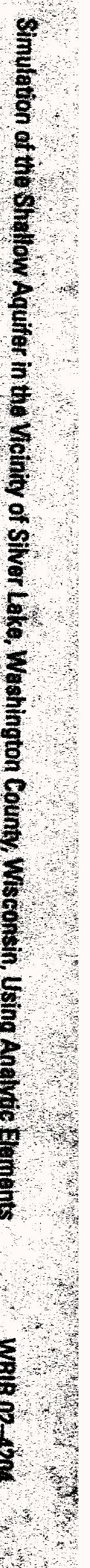

